\title{
Type 2 Diabetes Mellitus (T2DM): Biological Overview from Pathways to Organelles and its Translation toward a Torpid Wound Healing Process
}

\author{
Jorge Berlanga-Acosta ${ }^{1 *}$, Pedro López-Saura², Isabel Guillen-Pérez ${ }^{3}$, Gerardo Guillen-Nieto ${ }^{1}$, Boris Acevedo-Castro ${ }^{4}$ and Luis Herrera-
} Martínez ${ }^{4}$

${ }^{1}$ Biomedical Research Direction, Center for Genetic Engineering and Biotechnology, Cuba

${ }^{2}$ Clinical Trials Division, Center for Genetic Engineering and Biotechnology, Cuba

${ }^{3}$ Pharmacogenomics Department, Biomedical Research Direction, Center for Genetic Engineering and Biotechnology, Cuba

${ }^{4}$ Center for Genetic Engineering and Biotechnology, Cuba

\begin{abstract}
T2DM is a heterogeneous group of metabolic diseases characterized by hyperglycemia resulting from defects in insulin secretion, insulin action, or both. Hyperglycemia may simply represent the tip of a broad series of molecular events from mitochondrial damages, to epigenetic and metabolic pathways deregulations. At the same time, hyperglycemia appears as the most proximal trigger for the onset and perpetual progression of multi-organ complications even under normoglycemic conditions. Thus, the initial hyperglycemic hit translates into a permanently harmful cellular imprinting as has been demonstrated in diabetic donors' cells after several passages and cultured in ideal conditions. The wound healing failure along with the inability of the innate immunity to control peripheral infections is the hybrid that determines that $85 \%$ of all non-traumatic lower extremity amputations are practiced in diabetic subjects. Diabetic wounds exhibit a complex networking of inflammatory cytokines, local proteases, cytotoxic reactive oxygen and nitrogen species and a polymicrobial biofilm that impose a stagnant phenotype. All these ingredients negatively impact on fibroblasts, endothelial cells and keratinocytes while paradoxically perpetuate the immuno-inflammatory infiltrate. Although the molecular fundamentals toward chronification have not been elucidated, it seems that different gene simultaneously converge to impose the wound cells a pro-senescent, pro-catabolic and pro-apoptotic phenotype given the lack of a "physiological tuning" of tyrosine kinase-dependent receptors due to their limited activation by insulin and local growth factors. Although recombinant growth factors and smart devices have been introduced during the last years the figures of amputations are still discouraging. Faults have been committed while selecting the appropriate growth factor and because of the "chronic" instinct to treat the chronic wounds topically, where bioavailability of the active principle is compromised by wound and bacterial biofilm proteases. The periodic intralesional infiltration of epidermal growth factor has proved to overcome this hurdle. Granulation tissue growth stimulation and wound healing capacity has been restored in diabetic patients by this procedure in several clinical trials and common clinical practice studies.
\end{abstract}

Keywords: Diabetes; Ulcer; Amputation; Granulation tissue; Reepithelialization

\section{Introduction}

The current understanding on the molecular mechanisms impairing wound healing in diabetic subjects has progressively expanded over the last 20 years. Although we are still far from detailing the pathways toward wound chronification, diabetes- molecular factors that enforce fibroblasts, pericytes, keratinocytes and endothelial cells to precocious senescence, arrest and apoptosis have been identified to some extent [1-3].

Diabetes has rapidly increased in global prevalence, morbidity and mortality [4]. Diabetic foot ulcers (DFUs) are estimated to occur in $15 \%$ of all patients with diabetes [5] and precede $84 \%$ of all diabetes-related lower-leg amputations [6]. These figures suggest the existence of a gap between the bench-derived molecular progresses and wound management in daily practice. Diabetic foot ulcer healing represents a considerable investigational and clinical challenge and the treatment requires in addition to education and resources, an integral multidisciplinary approach to succeed in reducing amputation rates [7].

The general outcome of diabetic foot ulcers management is poor and there is continuing uncertainty concerning optimal approaches to confront it [8]. As a response, judicious strategies as the molecularguided approaches in a style of "personalized wound management" have started to hatch [9].
This review would hopefully offer a comprehensive notion about the entangled biochemical pathways of T2DM and its relationship with torpid healing as one of its complications. Special focus is addressed on the current lines of evidences about the toxic resonance of acute and long term exposure to high glucose on granulation tissue building blocks: fibroblasts and endothelial cells. We have included a characterization of the diabetic granulation tissue organizational disorders. The rationale and fundamentals for a unique pharmacological intervention to deal with high-grade ulcers are also presented. This EGF-based intervention is distinguished by the fact that its delivery procedure is based on the ulcer bed infiltration thus ensuring bioavailability to woundresponsive cells. The literature search was based on English language

*Corresponding author: Jorge Berlanga-Acosta, Wound Healing and CytoProtection Research Group, Biomedical Research Direction, Center for Genetic Engineering and Biotechnology, Havana 10600, PO Box: 6162, Havana, Cuba, Tel: 53-7-271 60 22; Fax: 53-7-250 44 94; E-mail: jorge.berlanga@cigb.edu.cu

Received July 16, 2013; Accepted August 14, 2013; Published August 20, 2013

Citation: Berlanga-Acosta J, López-Saura P, Guillen-Pérez I, Guillen-Nieto G, Acevedo-Castro B, et al. (2013) Type 2 Diabetes Mellitus (T2DM): Biological Overview from Pathways to Organelles and its Translation toward a Torpid Wound Healing Process. J Diabetes Metab 4: 285. doi:10.4172/2155-6156.1000285

Copyright: (c) 2013 Berlanga-Acosta J, et al. This is an open-access article distributed under the terms of the Creative Commons Attribution License, which permits unrestricted use, distribution, and reproduction in any medium, provided the original author and source are credited. 
Citation: Berlanga-Acosta J, López-Saura P, Guillen-Pérez I, Guillen-Nieto G, Acevedo-Castro B, et al. (2013) Type 2 Diabetes Mellitus (T2DM): Biological Overview from Pathways to Organelles and its Translation toward a Torpid Wound Healing Process. J Diabetes Metab 4: 285. doi:10.4172/2155-6156.1000285

Page 2 of 14

articles downloaded from Pubmed and Bioline International (www. bioline.org.br) data sources.

\section{General Overview of Type 2-Diabetes Mellitus (T2DM)}

T2DM may be conceptually defined as a heterogeneous group of metabolic diseases characterized by hyperglycemia resulting from defects in insulin secretion, insulin action, or both. It is important to note however that hyperglycemia may simply represent a distal and terminal aspect of a broad series of silent, individual molecular events, involving peripheral insulin resistance, rupture of glycogen homeostasis, and relative insulin secretion response failure. It is generally accepted that T2DM is a polygenic disorder composed of subtypes whereby genetic susceptibility is strongly associated with environmental factors. Thus, this metabolic epidemic explosion represents the phenotypic expression to a collision between genes and environment [10].

Evolutionarily glucose is a major energy source and is an important substrate for complex carbohydrates, protein and lipid synthesis in mammalian cells. It provides energy in the form of ATP through glycolysis and the citric acid cycle. It is also used in the formation of glycerol for triglyceride production and provides intermediates for the synthesis of fatty acids and non-essential amino acids. Mammalian cell glucose metabolism generates ATP through either aerobic or anaerobic pathways, thus providing the principal source of cellular energy and substrate storage. Glucose hydrophilic nature limits its trespassing through the cellular lipid bilayer, thus specific transporters are required for cells to incorporate it. Glucose carrier proteins (GLUTs) mediate insulin-stimulated glucose uptake. Nevertheless, glucose clearance is also mediated via insulin-independent mechanisms derived from the ability of plasma glucose to influence its own clearance by a mass action effect [11]

The regulation of glucose storage and endogenous production is central to blood glucose control. Gluconeogenesis and glucogenolysis are tightly regulated by hormones, enzymes, signaling pathways and cellular organelles. At the system level, organs like the liver, skeletal muscle, kidneys and adipose tissue play essential roles in glucose homeostasis. GLUTs mediate insulin-stimulated glucose uptake in these organs and tissues by a mechanism involving translocation between cellular compartments. GLUT isoforms expression is regulated by insulin and other factors such as hypoxemia, oxidative phosphorylation and osmotic stresses [12].

T2DM is characterized by a reduction of total body glucose clearance as compared with age and weight-matched controls [13]. This phenomenon includes insulin-independent [12] and insulindependent glucose clearance [14] as has been demonstrated in humans at risk of diabetes. Insulin action is not solely restricted to GLUTs regulation, but also to glucose homeostasis through hepatic glucose production suppression and stimulation of peripheral combustion [15]. At the end, the decline in peripheral glucose utilization and/ or excessive hepatic production constitutes a major ingredient in the so called insulin resistance whose major consequence is chronic hyperglycemia and/or hyperinsulinemia [16]

Different studies have shown that insulin resistance occurs at the hepatic and skeletal muscle levels. Insulin action signal transduction is impaired in skeletal muscle from T2DM subjects underscoring the contribution of molecular defects underlying the insulin resistant phenotype [12]. The fact that this process has been observed in cultured myoblasts after several passages suggests a genetic origin in connection with a heightened state of oxidative stress [17]. Insulin resistance is also a determinant factor in pancreatic $\beta$-cells failure. Factors limiting $\beta$-cell ability to respond to an increasing metabolic demand remain unknown, but likely involve genetic factors as well as glucotoxicity itself [18].

Hyperglycemia, along with insulin resistance and abnormal insulin and glucagon secretion, may alter glucose fluxes through specific pathways and cause glucose carbon to be shunted away from normal sites of storage. Furthermore, routes of glucose disposal are abnormal in diabetic subjects since glucose oxidation appears significantly reduced. Among other factors, an impaired mitochondrial activity might represent a basic defect in T2DM [19]. Thus, abnormal glucose storage and utilization in skeletal muscle and other tissues characterize T2DM, rendering an aberrant and uncontrolled pattern of proteins glycosylation [20]; which is a major contributing factor for the multisystem complications.

\section{Enzymes and pathways underlying T2DM}

As stated in the brilliant review by Bouche and co-workers (20) T2DM is a heterogeneous process so that multiple defects are necessary and permissive to the development of hyperglycemia [20]. Molecular approaches using gene expression profiling have demonstrated modifications in those encoding key enzymes involved in glycolysis, oxidative metabolism, and mitochondrial function associated with progressive insulin resistance and diabetes [20]. Some relevant examples of disease-associated gene expression modifications are shown in table 1 .

The first step in glucose metabolism is its phosphorylation, rendering glucose 6-phosphate (G-6-P) by hexokinases. Hexokinase II levels have been found to be low in skeletal muscle of diabetic subjects as compared with matched controls. A loss-of-function mutation of glucokinase has also been identified in some families with maturity onset diabetes of the young (MODY) [45]. These patients demonstrate decreased glucose phosphorylation and decreased insulin secretion [46]. On the other hand, increased endogenous glucose production is a consistent feature of T2DM which may be associated to an increased glucose-6-phosphatase activity [47].

The pyruvate dehydrogenase complex determines the transformation of pyruvate to acetyl-CoA (coenzyme A). This enzyme complex is inactivated by ATP when cellular energy stores are high and by pyruvate dehydrogenase kinase (PDK). Pyruvate dehydrogenase activity is less responsive to insulin stimulation both in patients with diabetes and in their offspring [48]. Furthermore, increased PDK4 activity has been observed in insulin resistance and T2DM subjects [27]. Other studies have suggested that inhibition of the glycolytic enzyme GAPDH (glyceraldehyde-3-phosphate dehydrogenase) could functionally divert upstream glycolytic metabolites into three major pathways mediating hyperglycemic damage: activation of protein kinase $\mathrm{C}$ (PKC) isoforms, hexosamine pathway flux, and advanced glycation end-product formation [49]. This concomitant impairment in the glucose oxidative pathway could render explanation as to why pyruvate- lactate interconversion rate is so greatly enhanced in T2DM patients. The hyperlactinemia may amplify insulin resistance by increased liver gluconeogenesis and decreased muscle glucose uptake [50].

Abnormal activation of glycogen synthase (GS) by insulin action has also been ascribed to T2DM individuals. Whether this is due to hyperglycemia or to a genetic defect has not been elucidated. In support to the first notion is the fact that GS activation was not found in cultured fibroblasts and skeletal muscle cells derived from 
Citation: Berlanga-Acosta J, López-Saura P, Guillen-Pérez I, Guillen-Nieto G, Acevedo-Castro B, et al. (2013) Type 2 Diabetes Mellitus (T2DM): Biological Overview from Pathways to Organelles and its Translation toward a Torpid Wound Healing Process. J Diabetes Metab 4: 285. doi:10.4172/2155-6156.1000285

Page 3 of 14

\begin{tabular}{|c|c|c|c|c|}
\hline Gene name and REFSEQ mRNAs & Protein localization & Biological function & $\begin{array}{l}\text { Relevance in the pathway of insulin } \\
\text { resistance (IR) }\end{array}$ & Reference \\
\hline $\begin{array}{l}\text { Hexokinase } 2 \\
\text { (HK2 or HKII) } \\
\text { NM_000189.4 }\end{array}$ & $\begin{array}{l}\text { Enzyme localized in various } \\
\text { compartments (cytoplasm, } \\
\text { membrane, mitochondrial } \\
\text { outer membrane) }\end{array}$ & $\begin{array}{l}\text { Hexokinases phosphorylate glucose } \\
\text { to produce glucose } 6 \text {-phosphate, thus } \\
\text { committing glucose to the glycolytic } \\
\text { pathway. The expression of this gene } \\
\text { is insulin responsive. }\end{array}$ & $\begin{array}{l}\text { Non-insulin dependent diabetes mellitus } \\
\text { (NIDDM) patients are characterized by } \\
\text { a reduced activity and a reduced gene } \\
\text { expression of HK2 in muscle, which may be } \\
\text { secondary to the metabolic perturbations. }\end{array}$ & {$[21,22]$} \\
\hline $\begin{array}{l}\text { Glucokinase (hexokinase 4)." } \\
\text { (GCK) } \\
3 \text { alternative transcripts: } \\
\text { NM_000162.3 NM_033507.1 } \\
\text { NM_033508.1 }\end{array}$ & $\begin{array}{l}\text { Enzyme localized in various } \\
\text { compartments (cytosol, } \\
\text { nucleoplasm, cytoplasm, } \\
\text { nucleus). } \\
\text { Alternative splicing of } \\
\text { this gene results in three } \\
\text { tissue-specific forms of } \\
\text { glucokinase, one found in } \\
\text { pancreatic islet beta cells } \\
\text { and two found in liver. }\end{array}$ & $\begin{array}{l}\text { Hexokinases phosphorylate glucose } \\
\text { to produce glucose- } 6 \text {-phosphate, the } \\
\text { first step in most glucose metabolism } \\
\text { pathways. This enzyme regulates } \\
\text { carbohydrate metabolism by acting } \\
\text { as a glucose sensor. It is not inhibited } \\
\text { by its product glucose-6-phosphate } \\
\text { but remains active while glucose is } \\
\text { abundant. }\end{array}$ & $\begin{array}{l}\text { Mutations in this gene have been associated } \\
\text { with: NIDDM, Maturity onset diabetes of } \\
\text { the young, type } 2 \text { (MODY2), persistent } \\
\text { hyperinsulinemic hypoglycemia of infancy } \\
\text { (PHHI). }\end{array}$ & {$[23,24]$} \\
\hline $\begin{array}{l}\text { Pyruvate dehydrogenase lipoamide } \\
\text { kinase isozyme } 4 \\
\text { (PDK4) } \\
\text { NM_002612.3 }\end{array}$ & $\begin{array}{l}\text { Enzyme localized in various } \\
\text { compartments (cytoplasm, } \\
\text { mitochondrial inner } \\
\text { membrane, mitochondrial } \\
\text { matrix). }\end{array}$ & $\begin{array}{l}\text { It plays an important role in } \\
\text { maintaining normal blood glucose } \\
\text { levels under starvation, and is } \\
\text { involved in the insulin signaling } \\
\text { cascade. }\end{array}$ & $\begin{array}{l}\text { PDK4 plays a crucial role in glucose utilization } \\
\text { and lipid metabolism by regulating the } \\
\text { pyruvate dehydrogenase complex (PDC) and } \\
\text { is an emerging therapeutic target for type } 2 \\
\text { diabetes. }\end{array}$ & {$[25,26]$} \\
\hline $\begin{array}{l}\text { Pyruvate dehydrogenase kinase, } \\
\text { isozyme } 2 \\
\text { (PDK2) } \\
4 \text { alternative transcripts: } \\
\text { NM_001199898.1 } \\
\text { NM_001199899.1 } \\
\text { NM_001199900.1 NM_002611.4 }\end{array}$ & $\begin{array}{l}\text { Enzyme localized in various } \\
\text { compartments (cytoplasm, } \\
\text { mitochondrial matrix). }\end{array}$ & $\begin{array}{l}\text { This gene encodes a member } \\
\text { of the pyruvate dehydrogenase } \\
\text { kinase family. The encoded } \\
\text { protein phosphorylates pyruvate } \\
\text { dehydrogenase, down-regulating the } \\
\text { activity of the mitochondrial pyruvate } \\
\text { dehydrogenase complex. }\end{array}$ & $\begin{array}{l}\text { Plays an important role in maintaining normal } \\
\text { blood glucose levels under starvation, and } \\
\text { is involved in the insulin signaling cascade. } \\
\text { Overexpression of this gene may play a role in } \\
\text { both cancer and diabetes. Plays a role in cell } \\
\text { proliferation by regulating carbohydrate and } \\
\text { fatty acid metabolism. }\end{array}$ & [27] \\
\hline $\begin{array}{l}\text { Glyceraldehyde-3-phosphate } \\
\text { dehydrogenase } \\
\text { (GAPDH) } \\
\text { Two transcript variants: } \\
\text { NM_001256799.1 } \\
\text { NM_002046.4 }\end{array}$ & $\begin{array}{l}\text { Localized in various } \\
\text { compartments (condensed } \\
\text { chromosome, condensin } \\
\text { complex, condensin core } \\
\text { heterodimer, cytoplasm, } \\
\text { etc). }\end{array}$ & $\begin{array}{l}\text { GAPDH is a key enzyme in } \\
\text { glycolysis that catalyzes the first } \\
\text { step of the pathway by converting } \\
\text { D-glyceraldehyde 3-phosphate } \\
\text { (G3P) into 3-phospho-D-glyceroyl } \\
\text { phosphate. }\end{array}$ & $\begin{array}{l}\text { GAPDH activates the major pathways } \\
\text { implicated in diabetic complications, including } \\
\text { advanced glycation end products (AGEs), } \\
\text { protein kinase } C \text {, and hexosamine pathway. }\end{array}$ & [28] \\
\hline $\begin{array}{l}\text { Protein kinase C } \\
(\text { PKC) isoforms } \\
\text { NM_002737.2 }\end{array}$ & $\begin{array}{l}\text { Localized in various } \\
\text { compartments } \\
\text { (cytoplasm, membrane } \\
\text { raft, mitochondrion, } \\
\text { nucleus, protein complex, } \\
\text { synaptosome). }\end{array}$ & $\begin{array}{l}\text { PKC is a family of serine/threonine } \\
\text { kinases that consist of } 12 \text { isoforms. } \\
\text { Theses enzymes are involved in } \\
\text { the control of the function of other } \\
\text { proteins. }\end{array}$ & $\begin{array}{l}\text { Activation of diacylglycerol (DAG)-protein } \\
\text { kinase C (PKC) pathway enhances polyol } \\
\text { pathway, increases oxidative stress, and } \\
\text { the accumulation of advanced glycation end } \\
\text { products; all proposed as potential cellular } \\
\text { mechanisms by which hyperglycemia induces } \\
\text { many vascular abnormalities in renal, retinal, } \\
\text { and cardiovascular tissues in diabetic animals } \\
\text { and patients. }\end{array}$ & [29.30] \\
\hline $\begin{array}{l}\text { Glycogen synthase } \\
\text { (UDP-glucose-glycogen } \\
\text { glucosyltransferase) } \\
\text { (GYS1) } \\
\text { Two transcript variants: } \\
\text { NM_001161587.1 } \\
\text { NM_002103.4 }\end{array}$ & $\begin{array}{l}\text { Localized in key tissues } \\
\text { as skeletal muscle and } \\
\text { adipose tissue; as in } \\
\text { various compartments } \\
\text { as mitochondrion and } \\
\text { cytoplasm. }\end{array}$ & $\begin{array}{l}\text { This enzyme converts excess glucose } \\
\text { residues one by one into a polymeric } \\
\text { chain for storage as glycogen. It } \\
\text { is a key enzyme in glycogenesis. } \\
\text { Glycogen synthase plays an } \\
\text { important biological role in regulating } \\
\text { glycogen/glucose levels. }\end{array}$ & $\begin{array}{l}\text { Patients with type } 2 \text { diabetes normally exhibit } \\
\text { low glycogen storage levels because of } \\
\text { impairments in insulin-stimulated glycogen } \\
\text { synthesis and suppression of glycogenolysis. } \\
\text { Insulin stimulates glycogen synthase by } \\
\text { inhibiting glycogen synthase kinases or/and } \\
\text { activating protein phosphatase } 1 \text { (PP1) among } \\
\text { other mechanisms. }\end{array}$ & [31] \\
\hline $\begin{array}{l}\text { Glycogen synthase kinase (GSK-3) } \\
\text { Two isoforms in mammals, GSK- } \\
3 \alpha \text { and GSK-3 } \beta \\
\text { NM_001146156.1 } \\
\text { NM_002093.3 }\end{array}$ & $\begin{array}{l}\text { Protein is localized } \\
\text { predominantly in the } \\
\text { cytoplasm but is also } \\
\text { found in the nucleus. Its } \\
\text { subcellular localization is } \\
\text { changed in response to } \\
\text { stimuli. }\end{array}$ & $\begin{array}{l}\text { Serine/threonine kinase with } \\
\text { important roles in the regulation } \\
\text { of glycogen synthesis, protein } \\
\text { synthesis, gene transcription, and cell } \\
\text { differentiation in various cell types. } \\
\text { Constitutively active protein kinase } \\
\text { that acts as a negative regulator } \\
\text { in the hormonal control of glucose } \\
\text { homeostasis. }\end{array}$ & $\begin{array}{l}\text { Deregulation of the GSK-3 has been } \\
\text { implicated in the development of type } 2 \\
\text { diabetes mellitus. GSK-3 protein expression } \\
\text { and kinase activity are elevated in diabetes, } \\
\text { while selective GSK-3 inhibitors have shown } \\
\text { promise as modulators of glucose metabolism } \\
\text { and insulin sensitivity. }\end{array}$ & [32-34] \\
\hline $\begin{array}{l}\text { Glycogen phosphorylase. } \\
\text { (PYGL) } \\
\text { Two alternative transcripts: } \\
\text { NM_001163940.1 NM_002863.4 }\end{array}$ & $\begin{array}{l}\text { Protein is localizing in } \\
\text { various compartments } \\
\text { (cytoplasm, soluble fraction). }\end{array}$ & $\begin{array}{l}\text { Phosphorylase is an important } \\
\text { allosteric enzyme in carbohydrate } \\
\text { metabolism. PYGL breaks up } \\
\text { glycogen into glucose subunits. This } \\
\text { enzyme participates in the glycolysis } \\
\text { pathways, Insulin signaling pathway, } \\
\text { and sucrose metabolism. }\end{array}$ & $\begin{array}{l}\text { Glycogen phosphorylase activity is critical for } \\
\text { normal skeletal muscle function. Mutations in } \\
\text { liver PYGL inhibit the conversion of } \\
\text { glycogen to glucose and results in moderate } \\
\text { hypoglycemia. The inhibition of PYGL has } \\
\text { been proposed as one method for treating } \\
\text { type 2-diabetes. Inhibiting the release of } \\
\text { glucose from the liver glycogen supply } \\
\text { appears to be a valid approach. }\end{array}$ & [35-37] \\
\hline
\end{tabular}


Citation: Berlanga-Acosta J, López-Saura P, Guillen-Pérez I, Guillen-Nieto G, Acevedo-Castro B, et al. (2013) Type 2 Diabetes Mellitus (T2DM): Biological Overview from Pathways to Organelles and its Translation toward a Torpid Wound Healing Process. J Diabetes Metab 4: 285. doi:10.4172/2155-6156.1000285

Page 4 of 14

\begin{tabular}{|c|c|c|c|c|}
\hline $\begin{array}{l}\text { Protein phosphatase 1, regulatory } \\
\text { (inhibitor) subunit 3A. (PPP1R3A) } \\
\text { NM_002711.3 }\end{array}$ & $\begin{array}{l}\text { Proteins are localized in } \\
\text { various compartments } \\
\text { (cytoplasm, membrane, } \\
\text { integral to membrane). }\end{array}$ & $\begin{array}{l}\text { Participate in insulin signaling } \\
\text { pathway, carbohydrate metabolic } \\
\text { process and glycogen metabolic } \\
\text { process. }\end{array}$ & $\begin{array}{l}\text { This gene has been associated to insulin } \\
\text { resistance and type 2-diabetes. }\end{array}$ & [38] \\
\hline $\begin{array}{l}\text { Glucagon-like peptide } 1 \text { receptor. } \\
\text { (GLP1R) } \\
\text { NM_002062.3 }\end{array}$ & $\begin{array}{l}\text { Protein is localized in } \\
\text { various compartments } \\
\text { (integral to membrane, } \\
\text { plasma membrane). }\end{array}$ & $\begin{array}{l}\text { The protein encoded by this gene is } \\
\text { a member of the glucagon receptor } \\
\text { family of } G \text { protein-coupled receptors }\end{array}$ & $\begin{array}{l}\text { GLP1R is known to be expressed in } \\
\text { pancreatic beta cells. Activated GLP1R } \\
\text { stimulates the adenylyl cyclase pathway which } \\
\text { results in increased insulin synthesis and } \\
\text { release of insulin. Consequently GLP1R has } \\
\text { been suggested as a potential target for the } \\
\text { treatment of diabetes }\end{array}$ & {$[39,40]$} \\
\hline $\begin{array}{l}\text { Aldolase B, fructose-bisphosphate } \\
\text { (ALDOB) } \\
\text { NM_000035.3 }\end{array}$ & $\begin{array}{l}\text { Protein is localized in } \\
\text { various compartments } \\
\text { (cytosol, lysosome, } \\
\text { microsome and others). }\end{array}$ & $\begin{array}{l}\text { Fructose-1,6-bisphosphate aldolase } \\
\text { is a tetrameric glycolytic enzyme that } \\
\text { catalyzes the reversible conversion } \\
\text { of fructose-1,6-biphosphate to } \\
\text { glyceraldehyde } 3 \text {-phosphate and } \\
\text { dihydroxyacetone phosphate. }\end{array}$ & $\begin{array}{l}\text { ALDOB is involved in cellular response to } \\
\text { extracellular stimulus; cellular responses to } \\
\text { insulin, glycolysis. It has been associated with } \\
\text { type2-diabetes. }\end{array}$ & {$[41,42]$} \\
\hline $\begin{array}{l}\text { Phosphofructoki-nase (PFK). } \\
4 \text { alternative transcripts in the liver: } \\
\text { NM_000289.5 } \\
\text { NM_001166686.1 } \\
\text { NM_001166687.1 } \\
\text { NM_001166688.1 }\end{array}$ & $\begin{array}{l}\text { Protein is localized in } \\
\text { various compartments } \\
\text { (cytoplasm, membrane, } \\
\text { cytosol, soluble fraction). }\end{array}$ & $\begin{array}{l}\text { PFK is the most important } \\
\text { enzyme in glycolysis. Three } \\
\text { phosphofructokinase isozymes } \\
\text { exist in humans: muscle, liver and } \\
\text { platelet. These isozymes function } \\
\text { as subunits of the mammalian } \\
\text { tetramer phosphofructokinase, which } \\
\text { catalyzes the phosphorylation of } \\
\text { fructose-6-phosphate to fructose-1,6- } \\
\text { bisphosphate. }\end{array}$ & $\begin{array}{l}\text { A deficiency of phosphofructokinase can } \\
\text { be inherited due to the genetic disorder } \\
\text { glycogenosis type VII Tarui's disease. } \\
\text { Research has shown that this disease can } \\
\text { lead to insulin resistance and reduced insulin } \\
\text { secretion by beta cells. }\end{array}$ & {$[43,44]$} \\
\hline
\end{tabular}

Table 1: List of genes involved in glycolysis, oxidative metabolism, and mitochondrial function associated with progressive insulin resistance and diabetes.

T2DM patients [51]. Furthermore, studies of muscle biopsy samples after in vivo insulin stimulation showed decreased activation of the insulin receptor along with the PI 3-kinase activity in skeletal muscle of the patients as compared with control non-diabetic subjects [52]. Concomitantly GSK-3 (glycogen synthase kinase) protein levels and activity are elevated in skeletal muscle [53].

Of relevance for T2DM pathophysiology is the hexosamine pathway since the final step in hexosamine biosynthesis is the formation of UDP$\mathrm{N}$-acetylglucosamine and other nucleotide hexosamines. These are major substrates for protein glycosylation participating in glucotoxicity and glucose-induced insulin resistance. Glycosylation is a major player in diabetes systemic complications and biochemical disturbances, including gene transcription, insulin signaling, signaling pathways, and systemic endothelial dysfunction. In vivo experiments have shown that increasing the flux into the hexosamine pathway by various means induces defects in insulin secretion and action, including diminished insulin-stimulated glucose uptake [20]. Glutamine - fructose-6-P aminotransferase (GFAT) levels appear elevated in skeletal muscle of T2DM patients and chronic hyperglycemia is also associated with increased enzyme activity [54].

Finally, transcription factors that coordinately regulate genes encoding mitochondrial function alter the expression of those regulating oxidative phosphorylation. PGC- $1 \alpha$ is a PPAR $\gamma$ (peroxisome proliferator-activated receptor) coactivator that promotes mitochondrial biogenesis and is a powerful regulator of oxidative energy metabolism under conditions of both health and disease [55]. PGC-1 $\alpha$ levels are altered both in diabetes patients and in their offsprings, who are at high risk for developing the disease [56]. Figure 1 summarizes current concepts on T2DM pathophysiological cascade.

\section{Cellular organelles involved in T2DM pathogenesis}

The connection between hyperglycemia/insulin resistance and oxidative stress has been acknowledged for years. Moreover, an intrinsic impairment in oxidative capacity, increased oxidative stress and reactive oxygen species (ROS) levels are an important trigger and perpetuating factors for insulin resistance [57].
Insulin resistance is associated with reduced insulin-stimulated mitochondrial activity as the result of blunted mitochondrial plasticity. The seminal observation that insulin becomes intimately bound to mitochondria and microsomes, incited to postulate that the hormone affects oxidative phosphorylation. Ulterior studies showed a clear defect in oxidative phosphorylation in mitochondria from diabetic individuals, which appeared ameliorated following insulin intervention in both in vivo and in vitro systems [58]. Further investigations demonstrated that mitochondrial DNA depleted cells are not insulin responsive [59], suggesting that the insulin signal must interact with this organelle as a response checkpoint. In general terms T2DM individuals present acquired or inherited reductions of mitochondrial oxidative phosphorylation capacity, submaximal ADPstimulated oxidative phosphorylation and reduced mitochondrial plasticity [60]. Other investigators have succeeded in showing that insulin resistance is rapidly reversible upon exposure to agents that act as mitochondrial uncouplers, electron transport chain inhibitors, or mitochondrial superoxide dismutase (SOD) mimetics. Similar effects were observed with overexpression of mitochondrial SOD. These evidences place mitochondrial superoxide at the nexus between intracellular metabolism and the control of insulin action [61].

Hyperglycemia increases oxidative stress through several pathways. A major mechanism appears to be the overproduction of the superoxide anion by the mitochondrial electron transport chain. Mitochondria per se are a rich source of oxidative end products. In parallel, mitochondrial superoxide anion is severely implicated in insulin resistance. Reversion of $\mathrm{O}^{--}$production has proved to restore insulin sensitivity [62]. Insulin-resistant animal models have higher levels of superoxide production [63].

Diminished mitochondrial content in circulating cells is associated with decreased insulin sensitivity and could be a marker of altered content in insulin-responsive tissues. More specifically, mitochondrial area and function are decreased in muscle of obese and diabetic persons [64], and mitochondrial activity correlates closely to measures of insulin sensitivity. Likewise, mitochondrial dysfunction and decreased 


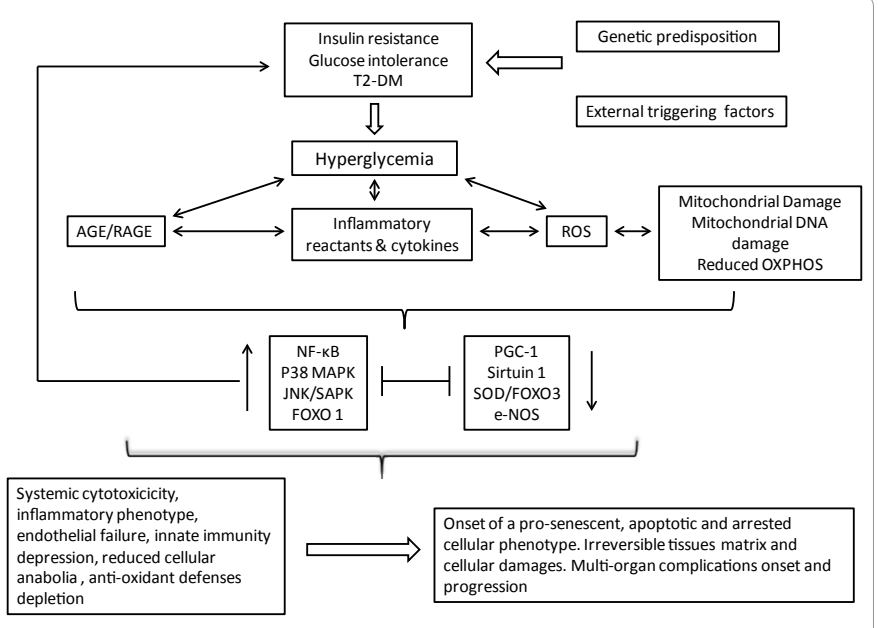

Figure 1: Molecular ingredients in T2DM and its complications pathophysiology. Studies based on cultured cells, gene transcriptional expression and epigenetic regulation have progressed to show that a number of gene/proteins appear to be "imprinted" as to predispose or to lead to insulin resistance and T2DM. Epidemiological studies have also shown the negative impact of environmental factors as life and diet styles. High glucose burden has proved to be toxic to cultured cells as to multiorgan systems under both acute and chronic exposure conditions. A line of evidences has shown that in humans and experimental animals, hyperglycemia is the proximal trigger for the activation of acute phase hepatic reactants and pro-inflammatory cytokines elevation in circulation. In a perpetuative vicious circle, the pro-inflammatory cytokines perturbs insulin receptor signal transduction and thus amplifies hyperglycemia. A cross-activation has been described between the receptor for advanced glycation-end products (RAGE) and the cytokines mediating the state of low grade inflammation in diabetes. Mounting evidences leave no room to doubt on the deleterious role of the advanced glycation-end products (AGE) accumulation. AGEs induce inflammation, apoptosis and cellular aging. On the other hand, hyperglycemia per se as in combination with pro-inflammatory cytokines reduces the cellular pool of anti-oxidant reserves and creates a pro-oxidant environment by the mitochondrial over-production of reactive oxygen species (ROS). These free radicals hamper the mitochondrial oxidative phosphorylation and provoke DNA damages. Under these oxidant and toxic environment, the cells activate signaling pathways and transcription factors that when their "fine tuning" is out of control lead to further amplification of cellular damages. In parallel, other gene/proteins involved in cells defense, anabolism, and survival become downregulated. It is worth noting to mention that hyperglycemia itself is toxic enough to reduce the expression of some of these genes or its derived proteins as e-NOS. As a consequence, cells become predisposed to onset a precocious senescent program, become refractory to programmed turnover and prone to apoptosis. These "cellular illness" translates into tissue and organs irreversible complications.

flux through the tricarboxylic acid cycle have been demonstrated to play an important role in the insulin resistance of aging [65].

As stated above, depletion of mtDNA causes insulin resistance with a drastic reduction in basal and insulin-stimulated glucose uptake and GLUT4 translocation in myocytes. The depletion of mtDNA causes a selective and reversible reduction in insulin receptor substrate (IRS-1) mRNA and protein levels and in insulin-stimulated IRS-1 and Akt2/ $\mathrm{PKB}$ phosphorylation [49]. Alterations in nuclear-encoded genes that regulate mitochondrial biogenesis, such as PGC-1- $\alpha$, AMP kinase, and CAM IV are considered as genetic basis for T2DM inheritance [66]. Although defects in insulin-stimulated muscle glucose transport and phosphorylation appear as very early events in the pathogenesis of T2DM, controversial data exist in the current literature regarding skeletal muscle mitochondrial biology in the pathogenesis of insulin resistance. Conclusively, if mitochondrial dysfunction is not the major culprit in insulin resistance and T2DM pathophysiology; the organelle dysfunction is at least an active player [67].
The endoplasmic reticulum (ER) is a membranous synthesis, metabolism, and transport organelle with vital roles in multiple processes that include the synthesis and processing of proteins and lipids, regulation of glucose and calcium homeostasis. ER acts as a quality control organelle to ensure that the newly made proteins are folded into their correct configuration. A failure in this control leads to accumulation of unfolded proteins that are toxic to cells resulting in a state known as ER stress. The relationship between ER stress and diabetes derived from 1980's investigations showing that ER function inducing compounds can normalize glucose-insulin homeostasis and eliminate insulin resistance and T2DM. Today it is acknowledged that ER stress plays a central role in peripheral insulin resistance and T2DM at the molecular, cellular, and organism levels [68]. The well-known diabetic glucolipotoxicity is a metabolic stress that induces ER stress and the unfolded protein response (UPR), which, up to a limit, can afford erroneous protein synthesis reduction and an increase in chaperones manufacture, required for proper protein folding. The disrupted ER function also affects the fate of glucose and promotes hyperglycemia through insulin resistance, stimulation of hepatic glucose production, and suppression of glucose disposal [69] by affecting insulin receptor signaling via c-Jun $\mathrm{N}$-terminal kinase (JNK) hyperactivation and subsequent serine phosphorylation of insulin receptor substrate-1 (IRS-1) [70]. The ER stress is also a major source of reactive oxygen species, which establishes a link with mitochondrial dysfunction, proinflammatory cytokine expression and insulin resistance via activation and nuclear translocation of nuclear factor $\kappa \mathrm{B}(\mathrm{NF \kappa B})$ [71].

\section{Diabetic Complications- The Wound Healing Failure}

Diabetic chronic and uncontrolled hyperglycemia can result in significant morbidity and mortality from macro- and microvascular complications to lower limb amputation [4]. The significance of these complications is emphasized by the fact that someone in the world dies from diabetes-related complications every seven seconds [72] and diabetes is now the leading cause of kidney failure and lower limb amputations globally [73]. Although a thorough incursion into the molecular basis of diabetic multiorgan complications is not the main goal of this review, a brief mention to Michael Brownlee's unifying hypothesis is worthy. Hyperglycemia, conceptually defined as the proximal trigger of diabetic complications, has been authenticated through large-scale prospective studies such as the Diabetes Control and Complications Trial (DCCT/EDIC) and the UK Prospective Diabetes Study (UKPDS) [74,75]. According to the unifying hypothesis hyperglycemia unleashes the mitochondrial ROS overproduction causing tissue damage by five major mechanisms: increased flux of glucose and other sugars through the polyol pathway, increased intracellular formation of advanced glycation end-products (AGEs), increased expression of the receptor for advanced glycation end products and its activating ligands, activation of protein kinase $\mathrm{C}$ (PKC) isoforms, and overactivity of the hexosamine pathway [76]. Obviously, the spectrum and the magnitude of these complications are conditioned by genetic determinants of individual susceptibility as by the presence of independent accelerating factors.

It is important to highlight that large clinical trials have demonstrated that once initiated, these complications persist and continue to progress even after glycemic control is achieved. Thus the initial hyperglycemic hit translates into a permanently harmful cellular imprinting identified since 1993 as "metabolic memory". In other words, this term represents the ability to sustain and perpetuate diabetic complications involving epigenetic events [77]. 
The refractoriness to heal and the propensity of diabetic wounds for chronification even in metabolically compensated diabetic patients can be explained by virtue of the metabolic memory. Recent conclusive evidence has emerged from zebrafish diabetic models showing that impaired fin regeneration is a heritable process driven by metabolic memory-mediated epigenetic changes and not from hyperglycemia acute consequences as ROS and AGEs accumulation [78].

\section{The diabetic wound fibroblast}

The fibroblast is central to the wound healing process by secreting, contracting and remodeling the extracellular matrix (ECM). They also secrete growth factors as important messengers for mesenchymal-tomesenchymal and epithelial-mesenchymal communication, especially to establish the emerging basement membrane and subsequent reepithelialization. Therefore, any impediment to fibroblast function is deterrent for normal healing and may result in chronic, nonhealing wounds. Under the high glucose burden imposed by diabetes, cutaneous and extra cutaneous fibroblasts appear perturbed. For many years, in vitro models recreating "clinical hyperglycemia" have proved to disrupt normal fibroblasts physiology and derange the secretion of extracellular matrix ingredients. These experiments have suggested that high glucose concentration is the detonator of a downstream cascade of molecular disturbances for the cutaneous fibroblast [79]. Rowe and co-workers pioneered the in vitro models that demonstrated reduced; synthetic, proliferative and secreting capabilities in diabetic cutaneous fibroblasts [80]. In other parallel studies, high glucose concentrations proved to inhibit fibroblast proliferation, while the cells turned refractory to proliferate to growth factors such as insulin-like growth factor type-I (IGF-I) and epidermal growth factor (EGF) [81]. Following these attractive targets, Goldstein's findings allowed to establish the hypothesis that diabetic fibroblast replicative life span proportionally decline with subject predisposition under normal glucose concentrations, concluding that a persistent, heritable abnormality is present in mesenchymal tissues of overt diabetic and genetically predisposed subjects. Years later, Goldstein also announced that cells obtained from insulin-dependent or insulin-independent diabetic people not only exhibit abnormal replicative capacity in vitro, but that the aging process appeared more precociously than in nondiabetic counterparts [82]. Other studies showed that the addition of conditioned media from non-insulin-dependent diabetes mellitus wound fibroblasts induced a dose-dependent inhibition in normal fibroblast proliferation apparently related to elevated L-lactate levels [83]. This replicative refractoriness of diabetic fibroblasts has been reproduced by different groups in subsequent years, thus confirming the need for additional external supplements to ensure cell cycle progression [84].

In addition to the onset of a quiescent and senescent phenotype of diabetic wound fibroblasts, their ability for horizontal and vertical migration is also dramatically impaired when compared to normal donor cells in different migration assays [85]. Most of these attributes are reproduced under acute exposures to high glucose concentrations so that migration speed is reduced by $\sim 40 \%$ associated to a decrease in cell directionality and to non-productive protrusive events, such as loss of cell polarization, consistent with the increased activity of Racl and the projection of multiple lamellipodia. This experiment concluded that the generation of reactive oxygen species (ROS) may lie behind these abnormalities as they were partially or completely rescued by treatment with N-Acetyl-Cysteine (NAC) [86].

As a consequence of the cutaneous accumulation of advanced glycation-end products (AGEs), the skin collagen increases its biological age. Fibroblasts therefore are not excluded from the onset of a pro-senescent phenotype. Fibroblasts cultured and exposed to an AGE precursor reduce the ability to efficiently migrate because of reduced adherence to the matrix. This observation appeared associated to a higher level of misfolded proteins suggesting an ER stress along with extracellular regulated kinase $1 / 2(\mathrm{ERK} 1 / 2)$ and Akt pathways downregulation. AGEs precursors also induce oxidative stress and apoptosis via a cascade of apoptotic proteins as FOXO1, BIM and caspase-3 activation in cutaneous fibroblasts [87]. Attention has been paid during the last years to the role of FOXO1 activation in diabetic connective tissue cells as a major apoptotic effector of AGEs and tumor necrosis factor-alpha (TNF- $\alpha$ ). FOXO1 limits wound healing by inhibiting fibroblasts proliferation and promoting cell death $[88,89]$. Interestingly, insulin inactivates FOXO1 via Akt leading to its nuclear export and degradation. Defective insulin action in the skin has been proposed as an important mechanism contributing to wound healing defects in diabetes. Perhaps the assorted constellation of the hormone's pharmacological bounties (increased expression of endothelial nitric oxide synthase, vascular endothelial growth factor, and stromal-derived factor-1 $\alpha /$ SDF-1 $\alpha$ ) observed in experimental and clinical wounds when insulin is topically administered may be attributable to FOXO1 neutralization. Curiously, the acceleration of wound healing occurs in parallel to a local recovery in the expression of proteins involved in insulin signaling pathways [90].

Despite the broad molecular information supporting the diabetic wound fibroblast phenotype of migratory and proliferative arrest, intriguing evidences demand further research. For instance, what is the mechanism underlying the proliferative arrest and the prosenescent phenotype of the cells even under ideal culture conditions and successive culture passages? It is likely that the emerging findings on the impact of metabolic memory and its epigenetic imprinting make those cells to remind where they used to indwell.

\section{Diabetic wound endothelial cells}

Angiogenesis is a comprehensive term which indicates the physiological process involving the growth of new blood vessels or neovascularization. This is a vital process for embryological growth, tissue development, and wound healing. Different growth factor families as vascular endothelial growth factors (VEGF), fibroblast growth factor (FGF), angiopoietins, platelet-derived growth factor (PDGF), transforming growth factor- $\beta$ (TGF- $\beta$ ), in collaboration with other proteins such as integrins, cadherins and ephrins regulate angiogenesis by promoting endothelial cells recruitment, proliferation, migration, co-opting and collar stabilization.

There is an enormous and ever-growing body of evidence indicating the close correlation between hyperglycemia and the abnormalities in endothelial morphology and function [91]. The UK Prospective Diabetes Study (UKPDS) and Diabetes Control of Complications Trial (DCCT) found microvascular disease and hyperglycemia to be intrinsically related. Thus, anomalous angiogenesis is a hallmark of both type forms of diabetes which is clearly and early observable during the process of granulation tissue growth, condition that has been successfully reproduced in animal models [92]. Furthermore, insulin has a dramatic impact on the endothelial homeostasis by its ability to stimulate $\mathrm{NO}$ release via a cascade that involves activation of the phosphatidylinositol 3-kinase (PI3K)-Akt signaling and endothelial nitric oxide synthase (e-NOS) phosphorylation. The later being of paramount importance in angiogenesis and wound healing as described below [93]. As depicted for fibroblasts, high glucose and the glycated by-products exert a toxic effect on endothelial cells and the 
Citation: Berlanga-Acosta J, López-Saura P, Guillen-Pérez I, Guillen-Nieto G, Acevedo-Castro B, et al. (2013) Type 2 Diabetes Mellitus (T2DM): Biological Overview from Pathways to Organelles and its Translation toward a Torpid Wound Healing Process. J Diabetes Metab 4: 285. doi:10.4172/2155-6156.1000285

Page 7 of 14

vascular wall in general. In parallel, the endothelial cells per se seem to be a very sensitive target to high glucose. Endothelial dysfunction is intricately related to insulin resistance through the stimulatory effects of insulin on glucose disposal and NO production in the endothelium. High glucose ambient has been shown to disturb endothelial cells cycle, disrupt tube formation, increase DNA damage, delay endothelial cells replication, and induce apoptosis [94]. In vitro models simulating "normoglycemia" and "hyperglycemia" have demonstrated that under a high glucose ambient, proliferation of dermal microvascular endothelial cells appear impaired [95] while apoptosis is enhanced [96] which may be related to the concomitant up-regulation of proinflammatory cytokines as TNF- $\alpha$, death receptors TNF-R1 and Fas ligand in a variety of cultured endothelial cells [97].

Hyperglycemia and the accumulation of AGEs disturb the role of angiogenic growth factors as VEGF, its receptor, its signaling pathway, thus affecting endothelial proliferation, migration, and endothelial progenitor cells (EPCs) release and recruitment. Insulin resistance interrupts the NO-mediated angiogenic positive regulation over angiogenic growth factors such as VEGF, FGF, and TGF- $\beta$ [98]. Compelling evidences indicate that at least a portion of the hyperglycemia and AGEs-mediated endothelial damages and dysfunctions are associated with an impaired mitochondrial activity resulting in mutations of mitochondrial DNA by a disproportionate reactive oxygen radical production leading to an inflammatory reaction and apoptosis [99]. In a similar manner many of the metabolic conditions associated with diabetes steam from a failure in $\mathrm{NO}$ synthesis or its precocious degradation. In this respect, the integrity of the Akt/e-NOS coupling pathway for a normal endothelial function appears compulsory [100].

Endothelial progenitor cells (EPCs) are active players for the maintenance and repair of endothelial cells. They participate in angiogenesis as they proliferate, migrate and differentiate, and are a source for proangiogenic factors and cytokines. Multiple evidences indicate that the number of circulating EPCs is decreased under both clinical forms of diabetes, which is likely to be involved in the pathogenesis of vascular complications [101]. Under experimental diabetic conditions the EPCs number appears significantly decreased in the bone marrow as in the peripheral blood which was reverted by treating the mice with insulin [102]. In general the bone marrowderived EPCs in the diabetic patients are considered as dysfunctional, producing fewer endothelial cells and with reduced replicative and migratory potential [103]. As to fully divert the physiological role of EPCs in tissue repair and angiogenesis, the duet hyperglycemia-ROS stimulate the EPCs to produce pro-inflammatory cytokines and to shift NO production by elevating i-NOS and decreasing e-NOS [104]. As described for other cells, AGEs treatment disrupts EPCs physiology thus leading to a downregulation of e-NOS and Bcl-2 expression, as well as an elevation in cyclo-oxygenase-2, Bax, NF- $\mathrm{kB}$, and caspase-3 in a MAPK (ERK/P38/JNK)-dependant manner [105].

The diabetes-mediated vascular damage is perhaps the most outspoken and ancestrally identified emblem of this disease. It is varied and broad as it is the concept of systemic endothelial dysfunction. Diabetes distorts the angiogenic program to ironically culminate with a misdistribution of soluble angiogenic factors: shortage where and when required (lower extremities skin) but overproduced where and when not needed (retina). It is also challenging to understand how and why microvascular morphological changes that recreate chronic, lifetime processes are readily identified in a 7-days old granulation tissue fragment, even in compensated patients. This incites to investigate which are the diabetes operational local and/or systemic forces that disrupt vascular morphogenesis.

\section{The diabetic granulation tissue}

Tissue regenerative capacity has been neglected along the species evolution. Thus, scarring process has emerged as an urgent alternative to favor the structural and functional restoration of a wounded zone. Within these events, the process of granulation tissue formation is pivotal as it constitutes a sort of living-temporary- aggregate of cells and proteins, acting as a welding material until tissue continuity is restored. However, the reluctance to trigger and sustain the out-growth of a productive granulation tissue with an appropriate extracellular matrix is typical in diabetic patients, particularly if ischemia concurs. As mentioned, these wounds are characterized by a proliferative arrest, pro-inflammatory, pro-oxidant and pro-degradative phenotype in which a spill-over of proteases degrades extracellular matrix ingredients, growth factors and their receptors [106].

This stubbornness to heal in diabetes is conditioned by systemic and local factors that in complicity counteract intrinsic reparative mechanisms. In a broad systemic context, inflammation and the anabolic deficit can be conceptually mentioned. Diabetic patients with foot ulceration confront alterations of the immune status with an active upregulation of circulating levels of acute-phase proteins, cytokines,

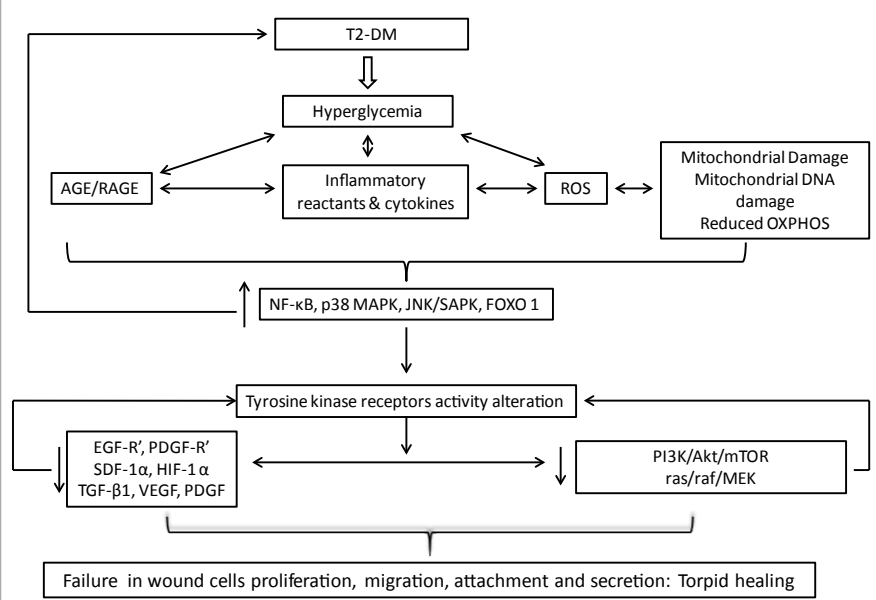

Figure 2: Putative relationship between T2DM and wound healing failure. Hyperglycemia has proved to arrest and perturb fibroblasts and keratinocytes migration as to promote endothelial cells apoptosis under culture conditions. Similar data have emerged from wound bed cells cultured in collagen matrices enriched with AGEs or AGEs precursors. Inflammatory cytokines and ROS spill-over impair mitochondrial function and impose the previously described cellular reactive phenotype so that cells defense reserves are maximally activated. Under this reactive cellular phenotype the pool of growth factors within the wound is reduced. Accordingly, the growth factors-mediated tyrosine kinase activity becomes consequently reduced. This basal constitutive tyrosine kinase receptorsmediated activity ensures the motion of downstream master switches for cells survival, proliferation and anabolism. An example is the PI3K Akt/mTOR pathway. This pathway is indispensable for wound repair and tissue growth. The reduced tuning of tyrosine kinase receptors amplifies the pre-existing deficit of growth factors which consequently will reduce the ligands-mediated receptors activation. One of these growth factors is insulin itself. On the other hand, the NF-қB mediated pro-inflammatory cytokine TNF- $\alpha$ downregulates the activity of the most important profibrogenic and pro-granulation growth factor: transforming growth factor- $\beta 1$ (TGF- $\beta 1$ ). The overall consequence for the wound is the onse of a stagnant phenotype based on failure of fibroblasts, endothelial cells, and myofibroblasts to migrate, proliferate, secrete matrix, and induce contraction. 
and chemokines that impose a chronic systemic inflammatory profile, and amplify local wound inflammatory networks. The systemically elevated levels of pro-inflammatory response markers and the wound expression of cytokines and chemokines are among the culprits of the abnormal repair mechanism [106]. Another factor to be considered is that diabetes per se is a metabolic disease in which fuel metabolism is perturbed given the rupture of one of the most important anabolic axis of the organism: insulin/insulin-like growth factor type-I. The role of insulin in wound healing is well known by its anabolic effect on wound protein balance favoring synthesis and preventing degradation [107]. Both insulin and IGF-1 appear to act in part by the induction of ATF4 (CREB2), essential for the activation of mammalian target of the rapamycin complex 1 (m-TORC1), which in turn is required for protein synthesis via FOXO-dependent genes repression. At the end, protein synthesis and cellular anabolism prevails [108]. It seems that a finely tuned, constitutive activity level for the insulin and other growth factor tyrosine-kinase receptors is indispensable for cell physiology including the events encompassed within the healing process (Figure 2).

Fibroblasts are the main source of collagen, and the number of fibroblasts can be taken as a measure of repair by their collagen synthesis ability. It is much likely that the growth factors such as epidermal growth factor (EGF), transforming growth factor beta (TGF- $\beta 1$ ), insulin-like growth factor (IGF-I), and platelet-derived growth factor (PDGF) that stimulate fibroblasts proliferation, transdifferentiation and the synthesis of matrix components, appear in deficit in diabetic foot ulcers resulting in a scarce extracellular matrix formation. Numerous growth factors (TGF- $\beta 1$, IGF-I, PDGF) regulate the balanced expression of matrix metalloproteases and their tissue inhibitors (MMPs /TIMPs), while most of them exhibit an altered expression in diabetic foot ulcers. Moreover, the imbalance in the diabetic foot ulcers milieu between TGF- $\beta 1$ and TGF- $\beta 3$ in which the former appears down-regulated, may explain fibroblasts quiescence in terms of proliferation and secretion [109]. This phenomenon represents the deficit of one of the most potent pro-fibrogenic and fibroblast-mitogenic growth factors, which at the same time down regulates macrophages activation.

One of the main challenges for the diabetic wound healing is the structuring of a normal matrix in quantity and quality. In general, a poor extracellular matrix formation distinguishes diabetic foot

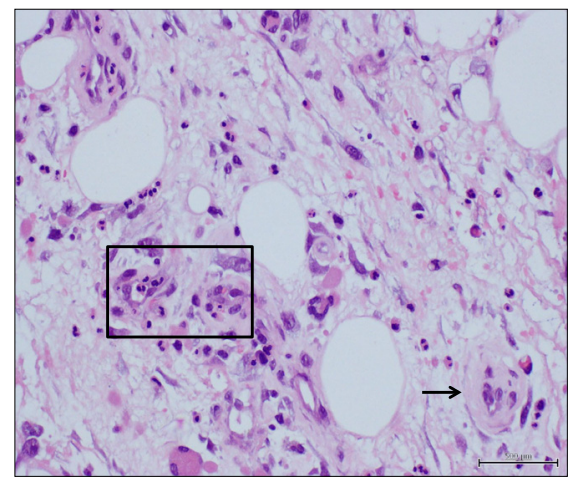

Figure 3: Histological aspect of a neuropathic ulcer granulation tissue. $\mathrm{H} / \mathrm{E} \times \mathbf{2 0}$. The absence of a mature and condensed extracellular matrix, given by thin collagen fibers and relative productive acellularity is a distinguishing aspect of the neuropathic granulation tissue. Inset: Abnormal vascular morphogenesis. Note the endothelial nuclear hypertrophy. Arrow: an incipient vessel with remarkably thickened wall. Note the almost complete luminal occlusion.

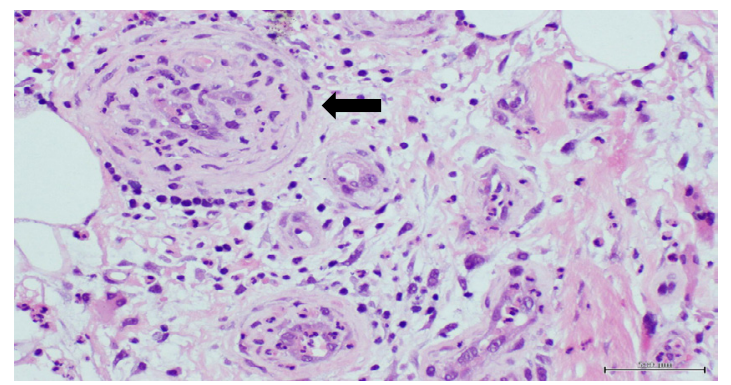

Figure 4: Histological aspect of an ischemic ulcer granulation tissue. H/E $\times 20$. Note that the abnormal angiogenesis is the predominant aspect of these wounds. The thick arrow indicates a vessel with a dramatic wall thickening with possible fusion of the tunica media and the perivascular collagen. Other thickened vessels can be observed. Endothelial nuclear hypertrophy and media nuclear polymorphism predominate.

ulcers, which can result from: (a) diminished synthesis, (b) increased degradation by proteolytic enzymes, (c) toxicity due to glycated by-products accumulation, and (d) toxicity by biofilm bacterial contaminants diffusion [110].

The diabetic granulation process does not generally exhibit the orderly cascade of events that characterize normal wound healing. This has been confirmed through the histopathological analysis of granulation tissue biopsies by Loots and co-workers who described the lesions as "frozen" in a chronic low-grade inflammatory state associated to a scarce provisional extracellular matrix [111]. Our group's serial biopsies from both neuropathic and ischemic ulcers-derived granulation tissue have identified histological differences for both types of wounds in the absence of clinical infection. Polymorphonuclear cells (PMN) infiltration is intense and prolonged particularly in neuropathic wounds, co-existing with a scarce extracellular matrix accumulation in which collagen deposit is impoverished (Figure 3). Under more mature stages, neuropathic lesions may also show an abnormal sprout of new small vessels and capillaries that may derive not from a normal angiogenic response but due to arteriovenous shunts. Our observations remind those of Black and co-workers who demonstrated that neuropathic patients exhibit a decrease in fibroblast proliferation and a scarce amount of collagen accumulation within the wound bed [112]. On the contrary, a broadly spread infiltration of round cells predominate in those patients suffering from wound bed ischemia, associated to a fibro-hyaline matrix of "hardened" aspect and abnormal angiogenesis in which vascular wall cellular mosaicism, precocious media thickening, endothelial nuclei hypertrophy and many other defects can be identified (Figure 4). It is likely that the combination of arterial hypoperfusion and glucose toxic derivatives imprint a particular pattern of damage to the morphogenesis of vessels within the wound [113]. These observations incite to speculate that the biochemical microenvironment in ischemic and neuropathic diabetic wounds is different and that the inflammatory "badge" is in correspondence with the wound's most prevalent pathogenic component. In contrast to acute wounds in non-diabetic subjects, the inflammatory reaction in diabetic appears prolonged, which sharply delays granulation tissue formation and maturation. Data derived from murine diabetic models indicate that the exaggerated inflammatory reaction is related to the prolonged expression of macrophage inflammatory protein-2 (MIP-2) and macrophage chemoattractant protein-1 (MCP-1) [114]. Furthermore, the down-regulation of the anti-inflammatory cytokine IL-10 in diabetic ulcers environment represents the collapse of an important inflammatory restrainer [115]. Other evidences indicate 
that PMNs are critical cells toward the acquisition and perpetuation of inflammation and a degradative phenotype. The granulocytes secrete TNF- $\alpha$ and IL- $1 \beta$, which act as a triggering signal for MMP expression via the common NF- $\kappa B$ signaling pathway. Importantly, the perpetuated homing of PMN within the wound bed is associated to high local levels of elastase secretion, ROS and reactive nitrogen species. High circulating and PMN-associated elastase levels are attributable to poor glycemia control and are currently considered as a risk marker for the development of diabetic angiopathy [116].

Wound contraction failure is a clinical hallmark of diabetic granulation tissue. Fibroblast-to-myofibroblast transdifferentiation represents a key event during wound healing and tissue repair. The contractile force generated by myofibroblasts as a highly specialized cell, speeds the healing process of dermal wounds in healthy humans, accounting for 80-90\% of scar tissue reduction [117]. In diabetes, all the biological factors that instrument the onset of a contractile phenotype/ activity become reduced, which seems to be mostly attributed to the deleterious activities of TNF- $\alpha$ within the wound, thus suppressing a-SMA expression [118].

As granulation tissue growth is the corollary of numerous cellular concerted events and converging soluble forces as growth factors, many more unanswered questions still remain as a challenge: 1) What are the driving forces underlying the microscopic structural differences between neuropathic and ischemic ulcer beds? 2) What explains the "inheritance" of vascular changes such as the Monckeberg's media thickening in nascent arteries within an incipient granulation tissue? 3) Why granulation tissue is histomorphologically abnormal even in metabolically compensated patients?

\section{The Rationale for a Novel Delivery Procedure. EGF Intralesional Infiltration is Justified and Improves Diabetic Wound Healing Response}

Topical application of recombinant human growth factors (GFs) dates back to almost 30 years. Their arrival sparked hopes as tissue healing magic bullets. To our understanding the setback stemmed from a rigorous clinical trial in which EGF was topically administered to acute, controlled and experimentally induced wounds in healthy volunteers [119] somewhat turned off the early medical enthusiasm. Accordingly, this clinical failure warned about the need for additional research in GFs pharmacology as in wounds biochemical environment. The study also suggested that even those acute, clean and controlled wounds in healthy subjects may not represent a 'comfortable' substrate for GFs physical and chemical integrity. Previous clinical evidences had already rendered disappointing results possibly because of local bioavailability limitations [120]. Unquestionably, the need to precondition the wound bed to preserve GFs local bioavailability for subsequent receptor stimulation and downstream signaling activation emerged as novel paradigmatic concepts [121]. This concept introduced by Mast and Schultz more than 20 years ago revolutionized wound healing pharmacology [122] and hitherto, a myriad of novel approaches to treat chronic wounds have been devised. Despite these historical messages, the topical application of growth factors onto the wound surface still remains as the most popular delivery method for growth factors and peptides [8].

Chronic wounds, particularly diabetic ones appear as a rich source of serine proteases, especially elastase which prompted the notion that optimal healing of chronic wounds may require to attenuate excessive proteolysis. Furthermore, diabetic wounds exhibit an exaggerated susceptibility to host an abnormal bacterial burden which produces proteases that degrade growth factors, their receptors, amplify the inflammatory response and deter growth factor storage within the extracellular matrix [123]. The existence of a peculiar biofilm that rapidly regenerate following sharp debridement, abundant in glycation-derived toxins, and characterized by a difficult to eradicate pathogenic polymicrobial community $[124,125]$, is another significant characteristic of diabetic foot ulcers (DFU). The understanding of the pathogenic significance of the biofilm in chronic wounds render current explanation on why topically administered growth factors may have failed in healing some chronic wounds. Today, decades of efforts toward growth factor pharmaceutical development may be considered a failure. The above mentioned data provides support for the premise that impaired GFs availability may act as a rate limiting factor in diabetic wound healing [126]. According to Smiell's analysis of 4 randomized studies, combining surgical debridement with the daily topical application of PDGF-BB a modest $15 \%$ improvement in the rate of fully healed diabetic ulcers was revealed as compared to placebo [127]. Other growth factors which at a moment were clinically investigated in the USA [128] vanished along the way because of lack of efficacy even when topically applied to acute, controlled, partial-thickness wounds in healthy volunteers. All these pieces of knowledge encouraged the search for more effective treatments and delivery strategies to ensure growth factor optimal activity. So far, these have included: (a) growth factor coding gene delivery to the wound cells through an adenoviral vector [129], (b) use of agents that inhibits metalloproteinases and TNF- $\alpha$ converting enzyme (TACE) [130], (c) wound bed preparation as to diminish wound microenvironment hostility [121].

The above described pieces of knowledge contributed to shape the idea that injecting EGF deep into the wound base and contours would allow for a larger pharmacodynamic response in terms of granulation tissue growth and wound closure. Another factor that nourished the idea of intralesional infiltration was the seminal finding of Cross and Roberts who showed very limited diffusion of radio labeled growth factors administered onto the wound surface, thus remaining into the upper levels of the granulating tissue [131]. In other words, these authors demonstrated that growth factors downward diffusion is actually hindered by a number of physical and chemical factors; thus becoming limitedly available for the responsive cells. It is noteworthy to mention that according to classic studies, the interaction between EGF and its receptor requires a prolonged time window interaction in order to commit wound cells for proliferation [132]. These ideas along with the animal experiences described below provided the rationale of the intralesional delivery via local infiltration.

Experiments from our group suggested a possible reduction of EGF bioavailability by proteases derived from non-infected, acute, controlled experimental wounds. It was somewhat surprising as other studies had already established proteolysis on GFs and their receptors in chronicity circumstances [133]. Further evaluations of cumulative profiles of radiolabeled EGF in a rat full-thickness wound model showed EGF degraded subspecies and a short residence time within the wound contours [134]. We had the experience of injecting EGF locally into denervated rat hind limbs upon sciatic nerve full-thickness cut. In addition to significantly assist in neurological restoration, the treatment enhanced limb peripheral soft tissue survival by delaying or preventing the onset of plantar ulcers and toe necrosis. The experiments offered an important lesson: locally injected EGF could stimulate the survival and repair of cutaneous and adjacent soft tissues in a context of circulatory neurogenic deterioration, somewhat similar to the diabetic lower limb 
Citation: Berlanga-Acosta J, López-Saura P, Guillen-Pérez I, Guillen-Nieto G, Acevedo-Castro B, et al. (2013) Type 2 Diabetes Mellitus (T2DM): Biological Overview from Pathways to Organelles and its Translation toward a Torpid Wound Healing Process. J Diabetes Metab 4: 285. doi:10.4172/2155-6156.1000285

clinical condition [135]. Trophic ulcers appeared to be prevented. We subsequently showed, by a series of experiments that single or repeated systemic or local EGF injections exerted 'clear-cut' cytoprotective and proliferative responses, supporting the intrinsic ability of EGF at supraphysiological concentrations to unleash biological events required for tissue repair [136]. These experiments in animals rendered the first pharmacological rationales for its infiltrative use in the treatment of diabetic foot ulcers, including ulcers under ischemic condition: (a) EGF contributed to attenuate lipid peroxidation and free radicals cytotoxicity, (b) EGF reduced local mediators of inflammation, (c) prevented cellular demise under episodes of ischemia/reperfusion, and (d) stimulated epithelial cells proliferation. Globally speaking, injected EGF could control three major ingredients of diabetic ulcers: inflammation, ischemia and oxidant cytotoxicity. The biological rationale for the intra and peri-lesional infiltration has been recently reviewed. The major fundamental is based on the finding of three major cellular stratums along the horizontal axis from the surface to the bottom of the granulation tissue in diabetic ulcers. The deeper layer expresses far more EGF receptors and far more cyclin D1 than the superficial counterpart. By the contrary, fibroblasts on the surface express far more AGE, prohibitin and elastase than those located at the depth. Thus, the infiltration not only by-passes chemical and physical barriers for degradation but also turns available EGF to those cells with larger EGF receptors expression and proliferative capability [137]. The first clinical evidences on EGF infiltrative treatment involved diabetic foot ulcers and amputation residual bases. All the lesions were chronic, complex and recalcitrant to heal, staged as grades III or IV of the Wagner's scale. The efficacy showed in this type of wounds [138] paved the way for a solid clinical development, which successfully culminated with a multicenter, double-blinded, placebo-controlled phase III clinical trial in which an unprecedented efficacy and safety profile were reported for high-grade ulcers [139-144]. Ongoing studies from our group (Jorge Berlanga-Acosta, unpublished data) have shown that locally infiltrated EGF is able to trigger acute and long term gene responses. Early gene response includes the up-regulation of proliferative, pro-survival and pro-anabolic genes. At the long term response (21 days after initiation) EGF induces the expression of a constellation of other growth factors that contribute to the healing process. In other words, the locally infiltrated EGF restores the deficit of growth factors brought about by diabetes and resumes the activity of tyrosine kinase receptors which appear crucial for the healing process, especially in the diabetic context where they are depressed [145].

A freshly published review by Lopez-Saura and co-workers in which the post-marketing clinical experience in more than 2000 subjects receiving intralesional EGF for advanced lesions was analyzed, confirmed the results of the clinical trials with $75 \%$ probability of complete granulation response, $61 \%$ healing, and a $16 \%$ absolute and $71 \%$ relative reduction of the risk of amputation. Outstandingly, the benefit includes ischemic patients and again a broad safety profile [146].

\section{Concluding Remarks}

Despite the presence of novel therapeutic agents developed against T2DM; an ordinary disease of the past has turned into a modern day pandemic. Since hyperglycemia is just the clinical tip of the iceberg and given the disease pathogenic complexity, T2DM poses as an investigational and clinical challenge. In addition to the broad constellation of enzymes, signaling switchers, transcription factors and mitochondria-controlling genes involved in the pathogenic cascade of T2DM; organelles like mitochondria and the endoplasmic reticulum are also committed. Notwithstanding the boundaries between cause and consequence and the individual commitment of each ingredient within the disease's puzzle remain blurry and elusive.

It is known that high glucose burden is toxic for fibroblasts, endothelial cells and keratinocytes. All these cells become arrested in migration and proliferation, gain a pro-senescent phenotype and may develop apoptosis. However, the fact that cultured fibroblasts and myocytes exhibit behavioral traits that have proved useful in predicting the onset of diabetes; and that some of these traits are shown by cultured cells from clinically healthy descendants of diabetic progenitors, indicate the responsibility of innate epigenetic and genetic heritable elements whose tunings is largely associated with external factors. In support to this notion is the recent enrichment of the Brownlee's unifying hypothesis with epigenetic changes as major rulers in the metabolic memory. The propensity of diabetic wounds for chronification in compensated patients is influenced by the matrix and cell metabolic memory. This relatively new concept remains treatmentorphan, appears irreversible and very much responsible for the multisystem complications progression. Thus, it is likely that T2DM and its complications will continue their striking course for years ahead. Although the molecular fundamentals of diabetic wound chronification are somewhat understood, the marriage between wound healing failure and diabetic innate immunity deficit tribute $80 \%$ of all non-traumatic amputations worldwide. This simple notion indicates that first and second line/high technology interventions such as recombinant molecules, bioactive dressings, subatmospheric pressure, and others, still exhibit an insufficient therapeutic impact. Oversized neuropathic ulcers are hard and long to heal. The ischemic ones, even undergoing satisfactory reperfusion procedures may take months to a year for re-epithelialization at the most optimistic scenario. Pharmacological doses of growth factors are intrinsically capable of resetting the diabetic wound bed cell biological competence by resuming the activation of different tyrosine kinase axis. The bioavailability limitations imposed by the wound environment in which the growth factors and their receptors are degraded, and those imposed by the limited physical diffusion of the proteins downward within the granulation tissue have limited growth factor incorporation to the clinical armamentarium. Thus far, the EGF infiltrative intervention stands as the unique pharmacological intervention jerking outsized and ischemic poor-prognosis wounds towards a rapid and sustained healing response.

\section{References}

1. Stojadinovic O, Brem H, Vouthounis C, Lee B, Fallon J, et al. (2005) Molecular pathogenesis of chronic wounds: the role of beta-catenin and c-myc in the inhibition of epithelialization and wound healing. Am J Pathol 167: 59-69.

2. Tomic-Canic M, Ayello EA, Stojadinovic O, Golinko MS, Brem H (2008) Using gene transcription patterns (bar coding scans) to guide wound debridement and healing. Adv Skin Wound Care 21: 487-492.

3. Schultz GS, Davidson JM, Kirsner RS, Bornstein P, Herman IM (2011) Dynamic reciprocity in the wound microenvironment. Wound Repair Regen 19: 134-148.

4. Matthews DR, Matthews PC (2011) Banting Memorial Lecture 2010^. Type 2 diabetes as an 'infectious' disease: is this the Black Death of the 21 st century? Diabet Med 28: 2-9.

5. Reiber GE, Vileikyte L, Boyko EJ, del Aguila M, Smith DG, et al. (1999) Causal pathways for incident lower-extremity ulcers in patients with diabetes from two settings. Diabetes Care 22: 157-162.

6. Reiber GE, Boyko EJ, Smith DG (1995) Lower extremity foot ulcers and amputations in diabetes. In: Harris MI, Stern MP, editors. Diabetes in America. 2nd ed. Bethesda, Maryland: National Diabetes Data Group: 409-428.

7. Sanders LJ, Robbins JM, Edmonds ME (2010) History of the team approach to amputation prevention: pioneers and milestones. J Vasc Surg 52: 3S-16S.

8. Game FL, Hinchliffe RJ, Apelqvist J, Armstrong DG, Bakker K, et al. (2012) A 
Citation: Berlanga-Acosta J, López-Saura P, Guillen-Pérez I, Guillen-Nieto G, Acevedo-Castro B, et al. (2013) Type 2 Diabetes Mellitus (T2DM): Biological Overview from Pathways to Organelles and its Translation toward a Torpid Wound Healing Process. J Diabetes Metab 4: 285. doi:10.4172/2155-6156.1000285

systematic review of interventions to enhance the healing of chronic ulcers of the foot in diabetes. Diabetes Metab Res Rev 28: 119-141.

9. Brem H, Sheehan P, Rosenberg HJ, Schneider JS, Boulton AJ (2006) Evidencebased protocol for diabetic foot ulcers. Plast Reconstr Surg 117: 193S-209S.

10. Groop L, Pociot F (2013) Genetics of diabetes - Are we missing the genes or the disease? Mol Cell Endocrinol.

11. Wilson-O'Brien AL, Patron N, Rogers S (2010) Evolutionary ancestry and nove functions of the mammalian glucose transporter (GLUT) family. BMC Evol Biol 10: 152 .

12. Karlsson HK, Zierath JR (2007) Insulin signaling and glucose transport in insulin resistant human skeletal muscle. Cell Biochem Biophys 48: 103-113.

13. DeFronzo RA, Gunnarsson R, Björkman O, Olsson M, Wahren J (1985) Effects of insulin on peripheral and splanchnic glucose metabolism in noninsulindependent (type II) diabetes mellitus. J Clin Invest 76: 149-155.

14. Martin BC, Warram JH, Krolewski AS, Bergman RN, Soeldner JS, et al. (1992) Role of glucose and insulin resistance in development of type 2 diabetes mellitus: results of a 25-year follow-up study. Lancet 340: 925-929.

15. Weyer C, Bogardus C, Mott DM, Pratley RE (1999) The natural history of insulin secretory dysfunction and insulin resistance in the pathogenesis of type 2 diabetes mellitus. J Clin Invest 104: 787-794.

16. Poitout V, Robertson RP (2002) Minireview: Secondary beta-cell failure in type 2 diabetes--a convergence of glucotoxicity and lipotoxicity. Endocrinology 143 339-342.

17. Bitar MS, Al-Saleh E, Al-Mulla F (2005) Oxidative stress--mediated alterations in glucose dynamics in a genetic animal model of type II diabetes. Life Sci 77 $2552-2573$.

18. Bernard-Kargar C, Ktorza A (2001) Endocrine pancreas plasticity under physiological and pathological conditions. Diabetes 50 Suppl 1: S30-35.

19. Woerle HJ, Szoke E, Meyer C, Dostou JM, Wittlin SD, et al. (2006) Mechanisms for abnormal postprandial glucose metabolism in type 2 diabetes. Am J Physio Endocrinol Metab 290: E67-67E77.

20. Bouché C, Serdy S, Kahn CR, Goldfine AB (2004) The cellular fate of glucose and its relevance in type 2 diabetes. Endocr Rev 25: 807-830

21. Braithwaite SS, Palazuk B, Colca JR, Edwards CW 3rd, Hofmann C (1995) Reduced expression of hexokinase II in insulin-resistant diabetes. Diabetes 44 $43-48$.

22. Vestergaard H, Bjørbaek C, Hansen T, Larsen FS, Granner DK, et al. (1995) Impaired activity and gene expression of hexokinase II in muscle from noninsulin-dependent diabetes mellitus patients. J Clin Invest 96: 2639-2645.

23. Matschinsky FM, Zelent B, Doliba N, Li C, Vanderkooi JM, et al. (2011) Glucokinase activators for diabetes therapy: May 2010 status report. Diabetes Care 34 Suppl 2: S236-243.

24. Agius $L$ (2009) Targeting hepatic glucokinase in type 2 diabetes: weighing the benefits and risks. Diabetes 58: 18-20.

25. Moon SS, Lee JE, Lee YS, Kim SW, Jeoung NH, et al. (2012) Association of pyruvate dehydrogenase kinase 4 gene polymorphisms with type 2 diabetes and metabolic syndrome. Diabetes Res Clin Pract 95: 230-236.

26. Lee FN, Zhang L, Zheng D, Choi WS, Youn JH (2004) Insulin suppresses PDK4 expression in skeletal muscle independently of plasma FFA. Am J Physiol Endocrinol Metab 287: E69-74.

27. Huang B, Wu P, Bowker-Kinley MM, Harris RA (2002) Regulation of pyruvate dehydrogenase kinase expression by peroxisome proliferator-activated receptor-alpha ligands, glucocorticoids, and insulin. Diabetes 51: 276-283.

28. Kanwar M, Kowluru RA (2009) Role of glyceraldehyde 3-phosphate dehydrogenase in the development and progression of diabetic retinopathy. Diabetes 58: 227-234.

29. Mackay K, Mochly-Rosen D (2001) Localization, anchoring, and functions of protein kinase $\mathrm{C}$ isozymes in the heart. J Mol Cell Cardiol 33: 1301-1307.

30. Noh H, King GL (2007) The role of protein kinase C activation in diabetic nephropathy. Kidney Int Suppl : S49-53.

31. Saltiel AR (2001) New perspectives into the molecular pathogenesis and treatment of type 2 diabetes. Cell 104: 517-529.
32. Henriksen EJ, Dokken BB (2006) Role of glycogen synthase kinase-3 in insulin resistance and type 2 diabetes. Curr Drug Targets 7: 1435-1441.

33. Tanabe K, Liu Z, Patel S, Doble BW, Li L, et al. (2008) Genetic deficiency of glycogen synthase kinase-3beta corrects diabetes in mouse models of insulin resistance. PLoS Biol 6: e37.

34. Amar S, Belmaker RH, Agam G (2011) The possible involvement of glycogen synthase kinase-3 (GSK-3) in diabetes, cancer and central nervous system diseases. Curr Pharm Des 17: 2264-2277.

35. Baker DJ, Timmons JA, Greenhaff PL (2005) Glycogen phosphorylase inhibition in type 2 diabetes therapy: a systematic evaluation of metabolic and functional effects in rat skeletal muscle. Diabetes 54: 2453-2459.

36. Somsák L, Nagya V, Hadady Z, Docsa T, Gergely P (2003) Glucose analog inhibitors of glycogen phosphorylases as potential antidiabetic agents: recent developments. Curr Pharm Des 9: 1177-1189.

37. Moller DE (2001) New drug targets for type 2 diabetes and the metabolic syndrome. Nature 414: 821-827.

38. Dunn JS, Mlynarski WM, Pezzolesi MG, Borowiec M, Powers C, et al. (2006) Examination of PPP1R3B as a candidate gene for the type 2 diabetes and MODY loci on chromosome 8p23. Ann Hum Genet 70: 587-593.

39. Drucker DJ, Philippe J, Mojsov S, Chick WL, Habener JF (1987) Glucagon-like peptide I stimulates insulin gene expression and increases cyclic AMP levels in a rat islet cell line. Proc Natl Acad Sci U S A 84: 3434-3438.

40. Samson SL, Garber A (2013) GLP-1R agonist therapy for diabetes: benefits and potential risks. Curr Opin Endocrinol Diabetes Obes 20: 87-97.

41. Munnich A, Besmond C, Darquy S, Reach G, Vaulont S, et al. (1985) Dietary and hormonal regulation of aldolase B gene expression. J Clin Invest 75: 10451052.

42. Ndisang JF, Lane N, Jadhav A (2009) The heme oxygenase system abates hyperglycemia in Zucker diabetic fatty rats by potentiating insulin-sensitizing pathways. Endocrinology 150: 2098-2108.

43. Rubio SI, Naha KK, Sivakumar K, Dalakas MC, Poretsky L (1996) Coexistence of diabetes and phosphofructokinase deficiency. Endocr Pract 2: 100-102.

44. Knobler H, Weiss Y, Peled M, Groner $Y$ (1997) Impaired glucose-induced insulin response in transgenic mice overexpressing the L-phosphofructokinase gene. Diabetes 46: 1414-1418.

45. Basu A, Basu R, Shah P, Vella A, Johnson CM, et al (2000) Effects of type 2 diabetes on the ability of insulin and glucose to regulate splanchnic and muscle glucose metabolism: evidence for a defect in hepatic glucokinase activity. Diabetes 49: 272-283.

46. Matschinsky FM (1996) Banting Lecture 1995. A lesson in metabolic regulation inspired by the glucokinase glucose sensor paradigm. Diabetes 45: 223-241.

47. Clore JN, Stillman J, Sugerman $\mathrm{H}(2000)$ Glucose-6-phosphatase flux in vitro is increased in type 2 diabetes. Diabetes 49: 969-974.

48. Mostert M, Rabbone I, Piccinini M, Curto M, Vai S, et al. (1999) Derangements of pyruvate dehydrogenase in circulating lymphocytes of NIDDM patients and their healthy offspring. J Endocrinol Invest 22: 519-526.

49. Du X, Matsumura T, Edelstein D, Rossetti L, Zsengellér Z, et al. (2003) Inhibition of GAPDH activity by poly(ADP-ribose) polymerase activates three major pathways of hyperglycemic damage in endothelial cells. J Clin Invest 112: 1049-1057.

50. DiGirolamo M, Newby FD, Lovejoy J (1992) Lactate production in adipose tissue: a regulated function with extra-adipose implications. FASEB J 6: 24052412

51. Ciaraldi TP, Nikoulina SE, Henry RR (2002) Role of glycogen synthase kinase-3 in skeletal muscle insulin resistance in Type 2 diabetes. J Diabetes Complications 16: 69-71.

52. Ciaraldi TP, Nikoulina SE, Bandukwala RA, Carter L, Henry RR (2007) Role of glycogen synthase kinase- 3 alpha in insulin action in cultured human skeleta muscle cells. Endocrinology 148: 4393-4399.

53. Ciaraldi TP, Oh DK, Christiansen L, Nikoulina SE, Kong AP, et al. (2006) Tissue-specific expression and regulation of GSK-3 in human skeletal muscle and adipose tissue. Am J Physiol Endocrinol Metab 291: E891-898.

54. Yki-Järvinen H, Daniels MC, Virkamäki A, Mäkimattila S, DeFronzo RA, et al. 
Citation: Berlanga-Acosta J, López-Saura P, Guillen-Pérez I, Guillen-Nieto G, Acevedo-Castro B, et al. (2013) Type 2 Diabetes Mellitus (T2DM): Biological Overview from Pathways to Organelles and its Translation toward a Torpid Wound Healing Process. J Diabetes Metab 4: 285. doi:10.4172/2155-6156.1000285

(1996) Increased glutamine:fructose-6-phosphate amidotransferase activity in skeletal muscle of patients with NIDDM. Diabetes 45: 302-307.

55. Finck BN, Kelly DP (2006) PGC-1 coactivators: inducible regulators of energy metabolism in health and disease. J Clin Invest 116: 615-622.

56. Patti ME, Butte AJ, Crunkhorn S, Cusi K, Berria R, et al. (2003) Coordinated reduction of genes of oxidative metabolism in humans with insulin resistance and diabetes: Potential role of PGC1 and NRF1. Proc Natl Acad Sci U S A 100: 8466-8471.

57. Houstis N, Rosen ED, Lander ES (2006) Reactive oxygen species have a causal role in multiple forms of insulin resistance. Nature 440: 944-948.

58. HALL JC, SORDAHL LA, STEFKO PL (1960) The effect of insulin on oxidative phosphorylation in normal and diabetic mitochondria. J Biol Chem 235: 15361539.

59. Park SY, Choi GH, Choi HI, Ryu J, Jung CY, et al. (2005) Depletion of mitochondrial DNA causes impaired glucose utilization and insulin resistance in L6 GLUT4myc myocytes. J Biol Chem 280: 9855-9864.

60. Szendroedi J, Phielix E, Roden M (2011) The role of mitochondria in insulin resistance and type 2 diabetes mellitus. Nat Rev Endocrinol 8: 92-103.

61. Hoehn KL, Salmon AB, Hohnen-Behrens C, Turner N, Hoy AJ, et al. (2009) Insulin resistance is a cellular antioxidant defense mechanism. Proc Natl Acad Sci U S A 106: 17787-17792.

62. Garcia-Roves PM (2011) Mitochondrial pathophysiology and type 2 diabetes mellitus. Arch Physiol Biochem 117: 177-187.

63. Blendea MC, Jacobs D, Stump CS, McFarlane SI, Ogrin C, et al. (2005) Abrogation of oxidative stress improves insulin sensitivity in the Ren-2 rat model of tissue angiotensin II overexpression. Am J Physiol Endocrinol Metab 288: E353-359.

64. Lee HK, Song JH, Shin CS, Park DJ, Park KS, et al. (1998) Decreased mitochondrial DNA content in peripheral blood precedes the development of non-insulin-dependent diabetes mellitus. Diabetes Res Clin Pract 42: 161-167.

65. Petersen KF, Befroy D, Dufour S, Dziura J, Ariyan C, et al. (2003) Mitochondrial dysfunction in the elderly: possible role in insulin resistance. Science 300 : $1140-1142$.

66. Parish R, Petersen KF (2005) Mitochondrial dysfunction and type 2 diabetes. Curr Diab Rep 5: 177-183.

67. Pagel-Langenickel I, Bao J, Pang L, Sack MN (2010) The role of mitochondria in the pathophysiology of skeletal muscle insulin resistance. Endocrine Rev 31: $25-51$.

68. Thomas SE, Dalton LE, Daly ML, Malzer E, Marciniak SJ (2010) Diabetes as a disease of endoplasmic reticulum stress. Diabetes Metab Res Rev 26: 611 621

69. Engin F, Hotamisligil GS (2010) Restoring endoplasmic reticulum function by chemical chaperones: an emerging therapeutic approach for metabolic diseases. Diabetes Obes Metab 12 Suppl 2: 108-115.

70. Ozcan U, Cao Q, Yilmaz E, Lee AH, Iwakoshi NN, et al. (2004) Endoplasmic reticulum stress links obesity, insulin action, and type 2 diabetes. Science 306 : 457-461.

71. Boden G (2009) Endoplasmic reticulum stress: another link between obesity and insulin resistance/inflammation? Diabetes 58: 518-519.

72. International Diabetes Federation (IDF) (2011) Global Diabetes Plan 20112021.

73. Shaw JE, Sicree RA, Zimmet PZ (2010) Global estimates of the prevalence of diabetes for 2010 and 2030. Diabetes Res Clin Pract 87: 4-14.

74. [No authors listed] (1993) The effect of intensive treatment of diabetes on the development and progression of long-term complications in insulin-dependent diabetes mellitus. The Diabetes Control and Complications Trial Research Group. N Engl J Med 329: 977-986.

75. [No authors listed] (1998) Intensive blood-glucose control with sulphonylureas or insulin compared with conventional treatment and risk of complications in patients with type 2 diabetes (UKPDS 33). UK Prospective Diabetes Study (UKPDS) Group. Lancet 352: 837-853.

76. Brownlee M (2005) The pathobiology of diabetic complications: a unifying mechanism. Diabetes 54: 1615-1625.
77. Intine RV, Olsen AS, Sarras MP Jr (2013) A zebrafish model of diabetes mellitus and metabolic memory. J Vis Exp : e50232.

78. Sarras MP Jr, Intine RV (2013) Use of Zebrafish as a Disease Model Provides a Unique Window For Understanding the Molecular Basis of Diabetic Metabolic Memory. In: Research on Diabetes. Hong Kong: iConcept Press Ltd.

79. Yevdokimova NY (2003) High glucose-induced alterations of extracellular matrix of human skin fibroblasts are not dependent on TSP-1-TGFbeta1 pathway. J Diabetes Complications 17: 355-364.

80. Rowe DW, Starman BJ, Fujimoto WY, Williams RH (1977) Abnormalities in proliferation and protein synthesis in skin fibroblast cultures from patients with diabetes mellitus. Diabetes 26: 284-290.

81. Hehenberger K, Hansson A (1997) High glucose-induced growth factor resistance in human fibroblasts can be reversed by antioxidants and protein kinase C-inhibitors. Cell Biochem Funct 15: 197-201.

82. Goldstein S (1984) Cellular and molecular biological studies on diabetes mellitus. Pathol Biol (Paris) 32: 99-106.

83. Hehenberger K, Heilborn JD, Brismar K, Hansson A (1998) Inhibited proliferation of fibroblasts derived from chronic diabetic wounds and normal dermal fibroblasts treated with high glucose is associated with increased formation of I-lactate. Wound Repair Regen 6: 135-141.

84. Grazul-Bilska AT, Luthra G, Reynolds LP, Bilski JJ, Johnson ML, et al. (2002) Effects of basic fibroblast growth factor (FGF-2) on proliferation of human skin fibroblasts in type II diabetes mellitus. Exp Clin Endocrinol Diabetes 110: 176 181.

85. Xue SN, Lei J, Yang C, Lin DZ, Yan L (2012) The biological behaviors of rat dermal fibroblasts can be inhibited by high levels of MMP9. Exp Diabetes Res 2012: 494579

86. Lamers ML, Almeida ME, Vicente-Manzanares M, Horwitz AF, Santos MF (2011) High glucose-mediated oxidative stress impairs cell migration. PLoS One 6: e22865.

87. Loughlin DT, Artlett CM (2011) Modification of collagen by 3-deoxyglucosone alters wound healing through differential regulation of p38 MAP kinase. PLoS One 6: e18676.

88. Storz $P$ (2011) Forkhead homeobox type $O$ transcription factors in the responses to oxidative stress. Antioxid Redox Signal 14: 593-605.

89. Siqueira MF, Li J, Chehab L, Desta T, Chino T, et al. (2010) Impaired wound healing in mouse models of diabetes is mediated by TNF-alpha dysregulation and associated with enhanced activation of forkhead box 01 (FOXO1) Diabetologia 53: 378-388.

90. Lima MH, Caricilli AM, de Abreu LL, Araújo EP, Pelegrinelli FF, et al (2012) Topical insulin accelerates wound healing in diabetes by enhancing the AKT and ERK pathways: a double-blind placebo-controlled clinical trial. PLoS One 7: e36974

91. Pirola L, Balcerczyk A, Okabe J, El-Osta A (2010) Epigenetic phenomena linked to diabetic complications. Nat Rev Endocrinol 6: 665-675.

92. Sonta T, Inoguchi T, Tsubouchi H, Sekiguchi N, Kobayashi K, et al. (2004) Evidence for contribution of vascular $\mathrm{NAD}(\mathrm{P}) \mathrm{H}$ oxidase to increased oxidative stress in animal models of diabetes and obesity. Free Radic Biol Med 37: 115 123

93. Efron DT, Most D, Barbul A (2000) Role of nitric oxide in wound healing. Curr Opin Clin Nutr Metab Care 3: 197-204.

94. Hink U, Li H, Mollnau H, Oelze M, Matheis $E$, et al (2001) Mechanism underlying endothelial dysfunction in diabetes mellitus. Circ Res 88: E14-22.

95. Jain M, LoGerfo FW, Guthrie P, Pradhan L (2011) Effect of hyperglycemia and neuropeptides on interleukin-8 expression and angiogenesis in derma microvascular endothelial cells. J Vasc Surg 53: 1654-1660.

96. Busik JV, Mohr S, Grant MB (2008) Hyperglycemia-induced reactive oxygen species toxicity to endothelial cells is dependent on paracrine mediators Diabetes 57: 1952-1965.

97. Rai NK, Suryabhan, Ansari M, Kumar M, Shukla VK, et al. (2005) Effect of glycaemic control on apoptosis in diabetic wounds. J Wound Care 14: 277-281.

98. Simons M (2005) Angiogenesis, arteriogenesis, and diabetes: paradigm reassessed? J Am Coll Cardiol 46: 835-837. 
Citation: Berlanga-Acosta J, López-Saura P, Guillen-Pérez I, Guillen-Nieto G, Acevedo-Castro B, et al. (2013) Type 2 Diabetes Mellitus (T2DM): Biological Overview from Pathways to Organelles and its Translation toward a Torpid Wound Healing Process. J Diabetes Metab 4: 285. doi:10.4172/2155-6156.1000285

99. Davidson SM, Duchen MR (2007) Endothelial mitochondria: contributing to vascular function and disease. Circ Res 100: 1128-1141.

100.Leo CH, Hart JL, Woodman OL (2011) Impairment of both nitric oxidemediated and EDHF-type relaxation in small mesenteric arteries from rats with streptozotocin-induced diabetes. Br J Pharmacol 162: 365-377.

101. Tamarat R, Silvestre JS, Le Ricousse-Roussanne S, Barateau V, LecomteRaclet L, et al. (2004) Impairment in ischemia-induced neovascularization in diabetes: bone marrow mononuclear cell dysfunction and therapeutic potential of placenta growth factor treatment. Am J Pathol 164: 457-466.

102. Saito H, Yamamoto $Y$, Yamamoto $H$ (2012) Diabetes alters subsets of endothelial progenitor cells that reside in blood, bone marrow, and spleen. Am J Physiol Cell Physiol 302: C892-901.

103. Loomans CJ, de Koning EJ, Staal FJ, Rookmaaker MB, Verseyden C, et al. (2004) Endothelial progenitor cell dysfunction: a novel concept in the pathogenesis of vascular complications of type 1 diabetes. Diabetes 53: 195199.

104. Reinhard H, Jacobsen PK, Lajer M, Pedersen N, Billestrup N, et al. (2010) Multifactorial treatment increases endothelial progenitor cells in patients with type 2 diabetes. Diabetologia 53: 2129-2133.

105.Shen C, Li Q, Zhang YC, Ma G, Feng Y, et al. (2010) Advanced glycation endproducts increase EPC apoptosis and decrease nitric oxide release via MAPK pathways. Biomed Pharmacother 64: 35-43.

106. Acosta JB, del Barco DG, Vera DC, Savigne W, Lopez-Saura P, et al. (2008) The pro-inflammatory environment in recalcitrant diabetic foot wounds. Int Wound J 5: 530-539.

107. Tuvdendorj D, Zhang XJ, Chinkes DL, Aarsland A, Kulp GA, et al. (2011) Intensive insulin treatment increases donor site wound protein synthesis in burn patients. Surgery 149: 512-518.

108. Adams CM (2007) Role of the transcription factor ATF4 in the anabolic actions of insulin and the anti-anabolic actions of glucocorticoids. J Biol Chem 282 16744-16753.

109. Galkowska H, Wojewodzka U, Olszewski WL (2006) Chemokines, cytokines, and growth factors in keratinocytes and dermal endothelial cells in the margin of chronic diabetic foot ulcers. Wound Repair Regen 14: 558-565.

110. Schultz G, Berlanga-Acosta J, Cowan L, Stechmiller J (2010) Linking the Advanced Glycation Endproducts/Receptor for Advanced Glycation Endproducts Pathway in Diabetics with Inflammation and Topical Antiinflammatory Treatments of Chronic Wounds. In: Sen CK, editor. Advances in Wound Care. New York: Mary Ann Liebert Inc: 248-252.

111. Loots MA, Lamme EN, Zeegelaar J, Mekkes JR, Bos JD, et al. (1998) Differences in cellular infiltrate and extracellular matrix of chronic diabetic and venous ulcers versus acute wounds. J Invest Dermatol 111: 850-857.

112. Black E, Vibe-Petersen J, Jorgensen LN, Madsen SM, Agren MS, et al. (2003) Decrease of collagen deposition in wound repair in type 1 diabetes independent of glycemic control. Arch Surg 138: 34-40.

113. Sliman SM, Eubank TD, Kotha SR, Kuppusamy ML, Sherwani SI, et al. (2010) Hyperglycemic oxoaldehyde, glyoxal, causes barrier dysfunction, cytoskeletal alterations, and inhibition of angiogenesis in vascular endothelial cells: aminoguanidine protection. Mol Cell Biochem 333: 9-26.

114. Wetzler C, Kampfer H, Stallmeyer B, Pfeilschifter J, Frank S (2000) Large and sustained induction of chemokines during impaired wound healing in the genetically diabetic mouse: prolonged persistence of neutrophils and macrophages during the late phase of repair. J Invest Dermatol 115: 245-253.

115. Weigelt C, Rose B, Poschen U, Ziegler D, Friese G, et al. (2009) Immune mediators in patients with acute diabetic foot syndrome. Diabetes Care 32 1491-1496.

116. Piwowar A, Knapik-Kordecka M, Warwas M (2000) Concentration of leukocyte elastase in plasma and polymorphonuclear neutrophil extracts in type 2 diabetes. Clin Chem Lab Med 38: 1257-1261.

117. Petrova N, Edmonds M (2006) Emerging drugs for diabetic foot ulcers. Expert Opin Emerg Drugs 11: 709-724.

118. Goldberg MT, Han YP, Yan C, Shaw MC, Garner WL (2007) TNF-alpha suppresses alpha-smooth muscle actin expression in human derma fibroblasts: an implication for abnormal wound healing. J Invest Dermatol 127 2645-2655.
119. Cohen IK, Crossland MC, Garrett A, Diegelmann RF (1995) Topical application of epidermal growth factor onto partial-thickness wounds in human volunteers does not enhance reepithelialization. Plast Reconstr Surg 96: 251-4.

120. Falanga V, Eaglstein WH, Bucalo B, Katz MH, Harris B, et al. (1992) Topical use of human recombinant epidermal growth factor (h-EGF) in venous ulcers. J Dermatol Surg Oncol 18: 604-606.

121. Sibbald RG, Orsted H, Schultz GS, Coutts P, Keast D; International Wound Bed Preparation Advisory Board; Canadian Chronic Wound Advisory Board (2003) Preparing the wound bed 2003: focus on infection and inflammation. Ostomy Wound Manage 49: 24-51.

122. Mast BA, Schultz GS (1996) Interactions of cytokines, growth factors, and proteases in acute and chronic wounds. Wound Repair Regen 4: 411-420.

123. Eming SA, Krieg T, Davidson JM (2007) Inflammation in wound repair: molecular and cellular mechanisms. J Invest Dermatol 127: 514-525.

124.Armstrong DG, Lipsky BA (2004) Diabetic foot infections: stepwise medica and surgical management. Int Wound J 1: 123-132.

125. Davis SC, Martinez L, Kirsner R (2006) The diabetic foot: the importance of biofilms and wound bed preparation. Curr Diab Rep 6: 439-445.

126. Eming SA, Kaufmann J, Löhrer R, Krieg T (2007) [Chronic wounds. Novel approaches in research and therapy]. Hautarzt 58: 939-944.

127. Smiell JM, Wieman TJ, Steed DL, Perry BH, Sampson AR, et al. (1999) Efficacy and safety of becaplermin (recombinant human platelet-derived growth factor-BB) in patients with nonhealing, lower extremity diabetic ulcers: a combined analysis of four randomized studies. Wound Repair Regen 7: 335346.

128. Barrientos S, Stojadinovic O, Golinko MS, Brem H, Tomic-Canic M (2008) Growth factors and cytokines in wound healing. Wound Repair Regen 16: 585-601.

129. Saaristo A, Tammela T, Farkkilā A, Kärkkäinen M, Suominen E, et al. (2006) Vascular endothelial growth factor-C accelerates diabetic wound healing. Am J Pathol 169: 1080-1087.

130. Stechmiller J, Cowan L, Schultz G (2010) The role of doxycycline as a matrix metalloproteinase inhibitor for the treatment of chronic wounds. Biol Res Nurs 11: 336-344.

131. Cross SE, Roberts MS (1999) Defining a model to predict the distribution of topically applied growth factors and other solutes in excisional full-thickness wounds. J Invest Dermatol 112: 36-41.

132. Buckley A, Davidson JM, Kamerath CD, Wolt TB, Woodward SC (1985) Sustained release of epidermal growth factor accelerates wound repair. Proc Natl Acad Sci U S A 82: 7340-7344.

133. Berlanga J, Lodos J, Reyes O, Caballero E, Lopez-Saura P (1998) Epidermal growth factor stimulated re-epithelialization in pigs. The possible role of acutewound proteases. Biotecnol Apl 15: 83-87.

134.Prats PA, Duconge J, Valenzuela C, Berlanga J, Edrosa CR, et al. (2002) Disposition and receptor-site binding of (125)I-EGF after topical administration to skin wounds. Biopharm Drug Dispos 23: 67-76.

135. Prats P, Castañeda O, Berlanga-Acosta J (1998) El factor de crecimiento epidérmico en lesiones del sistema nervioso periférico. Rev. Mexicana de Ciencias Farmacéuticas 29: 17-23.

136. Berlanga-Acosta J, Gavilondo-Cowley J, Lopez-Saura P, Gonzalez-Lopez T, Castro-Santana MD, et al. (2009) Epidermal growth factor in clinical practice - a review of its biological actions, clinical indications and safety implications. Int Wound J 6: 331-346

137. Berlanga-Acosta J (2011) Diabetic lower extremity wounds: the rationale for growth factors-based infiltration treatment. Int Wound J 8: 612-620.

138. Acosta JB, Savigne W, Valdez C, Franco N, Alba JS, et al. (2006) Epidermal growth factor intralesional infiltrations can prevent amputation in patients with advanced diabetic foot wounds. Int Wound J 3: 232-239.

139. Fernandez-Montequin JI, Infante-Cristia E, Valenzuela-Silva C, Franco-Perez N, Savigne-Gutierrez W, et al. (2007) Intralesional injections of Citoprot-P (recombinant human epidermal growth factor) in advanced diabetic foot ulcers with risk of amputation. Int Wound J 4: 333-343. 
Citation: Berlanga-Acosta J, López-Saura P, Guillen-Pérez I, Guillen-Nieto G, Acevedo-Castro B, et al. (2013) Type 2 Diabetes Mellitus (T2DM): Biological Overview from Pathways to Organelles and its Translation toward a Torpid Wound Healing Process. J Diabetes Metab 4: 285. doi:10.4172/2155-6156.1000285

Page 14 of 14

140. Fernandez-Montequin JI, Betancourt BY, Leyva-Gonzalez G, Mola EL, GalanNaranjo K, et al. (2009) Intralesional administration of epidermal growth factorbased formulation (Heberprot-P) in chronic diabetic foot ulcer: treatment up to complete wound closure. Int Wound J 6: 67-72.

141.Fernandez-Montequin JI, Valenzuela-Silva CM, Diaz OG, Savigne W, Sancho-Soutelo N, et al. (2009) Intra-lesional injections of recombinant human epidermal growth factor promote granulation and healing in advanced diabetic foot ulcers: multicenter, randomised, placebo-controlled, double-blind study. Int Wound J 6: 432-443.

142. Hernández Rivero MJ, Llanes Barrios JA, Acosta Lapera DS (2009) Heberprot-P, an effective therapy for prevention of diabetic foot amputation. Rev Cubana Angiol Cir Vasc 10: 3-11.

143. Valenzuela-Silva CM, Tuero-Iglesias AD, Garcia-Iglesias E, Gonzalez-Diaz O Del Rio-Martin A, et al. (2013) Granulation response and partial wound closure predict healing in clinical trials on advanced diabetes foot ulcers treated with recombinant human epidermal growth factor. Diabetes Care 36: 210-215.

144. López-Saura PA, Berlanga-Acosta J, Fernández-Montequín JI, ValenzuelaSilva C, González-Díaz O, et al. (2011) Intralesional Human Recombinant Epidermal Growth Factor for the Treatment of Advanced Diabetic Foot Ulcer: From Proof of Concept to Confirmation of the Efficacy and Safety of the Procedure. In: T D, editor. Global Perspective on Diabetic Foot Ulcerations. Rijeka (HR): InTech: 278.

145. Berlanga-Acosta J, Schultz GS, López-Mola E Guillen-Nieto G, GarcíaSiverio M, et al. (2013) Glucose toxic effects on granulation tissue productive cells: the diabetics' impaired healing. Biomed Res Int 2013: 256043.

146. López-Saura PA, Yera-Alos IB, Valenzuela-Silva C, González-Díaz O, RíoMartín A (2013) Medical Practice Confirms Clinical Trial Results of the Use of Intralesional Human Recombinant Epidermal Growth Factor in Advanced Diabetic Foot Ulcers. Adv Pharmacoepidemiol Drug Safety 2: 128.
This article was originally published in a special issue, Type 2 Diabetes Mellitus- Disease, Diagnosis \& Treatment handled by Editors. Dr. Judit Bene, University of Pécs, Hungary; Eun Seok Kang, Yonsei University College of Medicine, Korea 